\title{
TRADISI BAAYUN MULUD DI KOTA BANJARMASIN (Kajian Fenomenologis)
}

\author{
Arni, Maimanah \& Norhidayat \\ UIN Antasari Banjarmasin
}

Diterima tanggal 14 November 2017 / Disetujui tanggal 29 Desember 2017

\begin{abstract}
Banjarese people carry out the celebration or commemoration of the birthday of Prophet Muhammad Saw. with swinging children or adults, this event commonly referred to baayun mulud. The purpose of this event is based on various motives, both religious, sociological, and some other political-cultural motives. The religious motivation is the belief that it will be granted all the luck, get blessings, health, safety, recover from illness, child is not naughty / fussy and because nadzar which granted Allah Swt. The sociological motivation of this event is to cultivate the spirit of togetherness, mutually cooperation, and unity in the midst of urban society that tends to be individualist today. While the political-cultural motivation can be felt from the statement of the organizing committee who firmly stated that this event was held in order to revive a tradition that has been forgotten, whereas it used to exist in the time of the Sultanate of Banjar. Along with the reaffirmation of the existence of the Sultanate of Banjar, then the existence of culture that ever existed in the heyday of this Sultanate also tried to be raised again.
\end{abstract}

Kata kunci: Tradisi baayun mulud, masyarakat Banjar, mengayun anak

\section{Pendahuluan}

Bagi umat Islam di Indonesia, bulan Rabi'ul Awwal merupakan bulan penuh dengan keramaian dengan berbagai upacara yang diselenggarakan. Pada bulan ini berpadu tiga peristiwa penting sekaligus, yaitu peringatan hari kelahiran Nabi Muhammad Saw., hari wafatnya dan hijrahnya Nabi Saw. ke Madinah. Kaum muslimin selanjutnya menyebut hari kelahiran Nabi Muhammad Saw. dengan sebutan bulan maulid (bulan kelahiran) Nabi Muhammad Saw.

Dalam memperingati Maulid Nabi Muhammad Saw. di Indonesia, tampaknya telah benar-benar menjadi sebuah budaya religius yang mapan. Ia tidak hanya digelar di kalangan masyarakat awam, tetapi juga di kalangan istana negara oleh Presiden RI bersama jajaran pemerintahan sebagai agenda resmi kenegaraan, misalnya di Jawa Tengah, khususnya daerah 
Yogyakarta, perayaan maulid Nabi ini masuk ke dalam istana yang sarat dengan ritual adat istiadat istana. Sejak masa Demak, usaha Sunan Kalijaga perayaan maulid berkembang dalam istilah grebeg maulud atau sekaten ${ }^{1}$. Perayaan maulid ini melibatkan para ulama, pihak istana dan masyarakat umum. Di wilayah budaya keraton Solo, walaupun menggunakan istilah yang sama-grebeg maulud — dalam prosesi acara banyak hal yang berbeda, seperti pembacaan tahlil keraton yang menggunakan model zikir tarekat naqsabandiyah, serta pembacaan sabadat kures yang diajarkan oleh Katib Winong Kiai Keraton Kasunanan Surakarta. Selain itu di Cirebon juga memperingati maulid Nabi yang dilakukan di istana, dengan sebutan upacara panjang jimat, penyucian pusaka dengan cara memandikan alat-alat pusaka keraton.

Tidak hanya di daerah Yogyakarta dan Cerebon saja, upacara yang sama juga diselenggarakan di daerah Pemalang dengan cara yang berbeda. Pada tanggal 12 Rabiul Awwal masyarakat Pemalang menggelar tablil, jamasan dan tirakat di makam Syekh Pandanjati, sambil diiringi tabuhan rebana, alat-alat pusaka dibawa dengan tandu menuju lokasi penjamasan. Di kota ini peringatan maulid juga dirayakan dalam bentuk sedekah laut atau baritan sebagai wujud ungkapan rasa syukur para nelayan. Di sebagian masyarakat Sunda juga, maulid Nabi dirayakan dengan membacakan wawacan (seni baca naskah berbentuk langgam pupub) yang berisi tentang kisah-kisah nabi dengan bahasa Sunda dan bertuliskan huruf Arab. Di wilayah Jawa Timur, daerah Madura sebagaimana disitir dari buku Lebur Seni Musik dan Perunjukan dalam Masyarakat Madura, karya Helene Bouvier, perayaan maulid Nabi merupakan perayaan besar setara dengan perayaan Isra Mi'raj. Perayaan maulid diiringi berbagai jenis kesenian seperti hadrah, qasidah, sambil berarakarakan yang terkadang juga disertai dengan topeng-topengan raksasa dan macan. ${ }^{2}$

Selain itu, di daerah Padang Pariaman Sumatra Barat dan Maluku Utara juga Merayakan upacara maulud Nabi dengan cara yang berbeda. Di Padang Pariaman, perayaan maulid berlangsung lama, mencapai waktu satu setengah bulan karena perayaan diadakan dengan bergiliran antara satu kampung dengan kampung lainnya. Acara dimulai dari memasak lamang sebagai tanda tibanya bulan maulid, kemudian pembacaan zikir maulud, membawa jamba (nasi dengan segala lauk-pauknya) ke surau dan saling memberi lamang kepada sanak saudara. Di Maluku utara, di daerah Jati, masyarakat Gamkonora menyajikan dabus dalam perayaan maulid. Di Takalar menyebutnya perayaan maudu'lompoa (maulid besar) dengan menyajikan pembacaan rate sebuah kitab yang ditulis oleh Sayyid Jalaluddin yang dipercaya sebagai satu ajaran tarekat Nur Muhammad.

${ }^{1}$ Istilah grebeg artinya "mengeroyok", "mengepung" atau "mengerumuni”, di mana pada puncak peringatan ada ritual rebutan gunungan atau nasi tumpeng besar yang diyakini memberi berkah besar bagi siapa yang memakannya.

${ }^{2}$ GONG (Media Seni dan Pendidikan Seni) Yogyakarta, edisi 69/VII/2005, 8-11. 
Adapun di Banjarmasin, Kalimantan Selatan, perayaan maulid diperingati dengan serangkaian acara-acara, biasanya terdiri dari pembacaan syair-syair maulid, seperti: alBarzanji, al-Diba'i, Asyaraf al-Anam, atau maulid al-Habsyi. Dilanjutkan dengan ceramah agama. Peringatan maulid ini dilakukan di berbagai tempat, seperti: tempat-tempat ibadah; mesjid dan langgar (mushalla), sekolah-sekolah dan perkantoran, rumah-rumah penduduk, tempat-tempat keramat dan lain sebagainya. Masyarakat rela bergotong-royong untuk mempersiapkan segala sesuatu demi suksesnya perayaan ini. Biaya penyelenggaraannya pun mereka tanggung bersama-sama. Sementara itu, sebagian masyarakat Banjar, khususnya keturunan kerajaan, ada pula yang memperingati hari kelahiran Nabi Muhammad Saw. ini dengan menggelar suatu tradisi unik yang mereka sebut dengan istilah maayun anak. Karena tradisi maayun anak ini digelar seiring dengan peringatan hari kelahiran Nabi, yaitu pada bulan maulid, maka upacara ini dalam bahasa Banjar dinamakan dengan istilah baayun mulud.

Istilah "Baayun Mulud" sendiri terdiri dari 2 kata, yaitu: baayun dan mulud. Baayun sepadan dengan kata "berayun" dalam bahasa Indonesia, yang maknanya: bergantung dan bergerak ke depan dan ke belakang secara teratur; berbuai dengan menggunakan ayunan (sebuah perkakas yang bergantung untuk menidurkan anak biasanya terbuat dari rotan atau tali, kain panjang, dsb. ${ }^{3}$ Sedangkan mulud sepadan dengan kata "maulid" dalam bahasa Indonesia, yang maknanya: lahir (terutama hari lahir Nabi Muhammad Saw.). ${ }^{4}$ Dengan demikian, baayun mulud adalah acara mengayun seseorang, baik bayi ataupun orang dewasa, dengan menggunakan ayunan yang biasanya digunakan untuk menidurkan bayi, diiringi dengan pembacaan sya'ir-sya'ir maulid dan shalawat atas Nabi Muhammad Saw.

Berpadu dengan peringatan maulid Nabi, upacara baayun mulud ini biasanya diselenggarakan di mesjid-mesjid atau di tempat-tempat keramat (makam). Dalam penyelenggaraan acara baayun mulud yang digelar secara massal, banyak warga kampung yang berada jauh di luar kampung diundang hadir sehingga perayaan baayun mulud menjadi suatu ritus yang bersifat kontraksi sosial. Demikian pula perayaan baayun mulud yang dilaksanakan oleh keluarga-keluarga tertentu dalam suatu kampung, merupakan kontraksi bububan (keluarga besar). Bagi mereka yang merasa kelompok bubuhan atau keturunan kerajaan, tradisi baayun mulud ini merupakan suatu kebutuhan. Sebab, jika hal tersebut tidak diselenggarakan, akan berdampak buruk bagi si bayi, seperti sering sakit, cengeng, dan lainlain, yang menurut kepercayaan mereka karena dipingit datu (diganggu oleh ruh halus). ${ }^{5}$ Namun bagi sebagian yang lain, ikut dalam acara baayun mulud hanyalah sebagai pencerminan rasa syukur kepada Allah atas limpahan rahmat dan karunianya, yang telah mengutus Nabi 3, cet. ke-3, 81 .

${ }^{3}$ Tim Penyusun Kamus Pusat Bahasa, Kamus Besar Bahasa Indonesia (Jakarta: Balai Pustaka, 2003), ed.

${ }^{4}$ Tim Penyusun Kamus Pusat Bahasa, Kamus Besar Bahasa Indonesia, 725.

5Mochrani, Agama dan Kemasyarakatan (Banjarmasin: PPPTAI-IAIN, 1982), 1. 
Muhammad sebagai pembawa rahmat ke muka bumi, sehingga disambut dengan pembacaan syair-syair yang merdu.

Pada perkembangan sepuluh tahun terakhir ini, upacara baayun mulud semakin banyak diminati masyarakat, terbukti dengan semakin bertambahnya peserta yang hadir meramaikan, dan yang ikut maayun anak tidak lagi terbatas untuk keturunan kerajaan saja, tetapi juga orang yang bukan keturunan kerajaan. Yang lebih unik lagi, terkait dengan peserta yang diayun, bukan lagi hanya anak-anak tetapi juga orang dewasa, bahkan yang sudah tua (nenek-nenek). Mereka masing-masing mengikuti kegiatan ini dengan beragam kepercayaan dan motivasi tersendiri.

Penyelenggaraan acara baayun mulud di Banjarmasin, khususnya di daerah Kuin Utara, sebenarnya telah lama pudar. Hanya sekitar tujuh tahun terakhir ini dihidupkan kembali keberadaannya. Aktivitas baayun mulud di daerah ini dilaksanakan di depan makam Pangeran Surianyah, dan mereka yang ikut sebagai peserta datang dari berbagai daerah di Kalimantan Selatan bahkan ada yang datang dari luar Kalimantan Selatan, sebagaimana juga di mesjid Jami' Teluk Dalam.

Mencermati segala bentuk upacara peringatan maulid Nabi sebagaimana dikemukakan di atas, tidak bisa dipungkiri bahwa upacara itu sangat kaya dengan muatan budaya lokal sehingga memberi warna tersendiri dalam pelaksanaan peringatan maulid tersebut. Tata cara pelaksanaan di satu daerah berbeda dengan daerah lainnya, meski tidak menghilangkan semangat awal peringatan maulid itu sendiri, yaitu menghidupkan kembali semangat keagamaan dengan dibacakan riwayat Nabi Muhammad Saw. Berangkat dari realitas tersebut, tulisan ini mendeskripsikan tradisi Baayun Mulud di Banjarmasin sebagai bagian dari penelitian fenomenologis.

\section{Tradisi Baayun Anak dalam Literatur Islam}

Tidak dapat dipastikan dengan jelas kapan baayun anak pertama kali dimulai dan siapa orang pertama yang memulainya. Tampaknya kebiasaan menidurkan anak-anak yang masih bayi dalam ayunan sudah sejak lama sekali dikenal oleh umat manusia dari berbagai suku bangsa. Hal ini dapat diketahui dari isyarat-isyarat dalam kitab suci kaum muslimin. Dalam al-Qur'ân terdapat tiga ayat dalam tiga surat yang berbeda namun berbicara tentang hal yang senada, yaitu tentang keajaiban seorang bayi, dalam hal ini 'Isâ as., Putera Maryam yang sudah pandai bercakap-cakap meski masih berada dalam buaian (ayunan). Dalam Q.S. Âli Imrân: 46 dinyatakan,

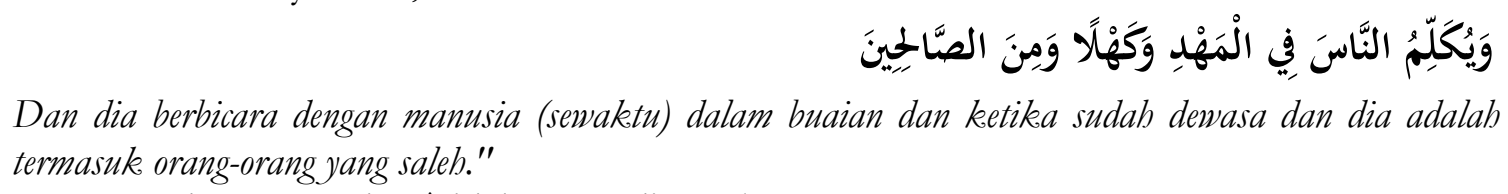

Dalam Q.S. al-Mâ idah: 110, ditegaskan: 


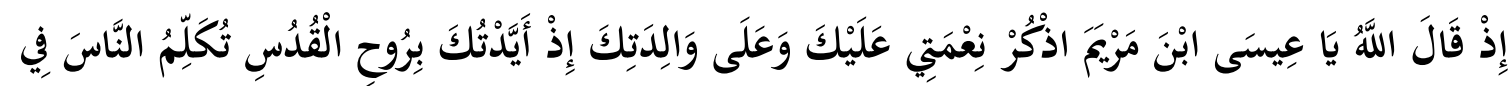

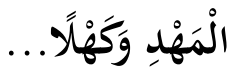
(ingatlah), ketika Allab berfirman: "Hai Isa putra Maryam, ingatlah nikmat-Ku kepadamu dan kepada ibumu sewaktu Aku menguatkan kamu dengan Rubul qudus. kamu dapat berbicara dengan manusia di waktu masih dalam buaian dan sesudah dewasa;

dan dalam Q.S. Maryam : 29, dikatakan:

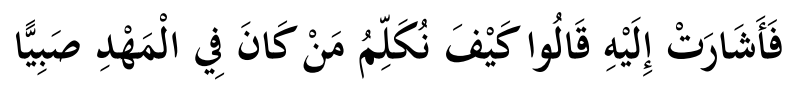

"Maka Maryam menunjuk kepada anaknya. mereka berkata: "Bagaimana kami akan berbicara dengan anak kecil yang masib di dalam ayunan?"

Selain 'Isâ as., terdapat pula bayi-bayi lainnya yang juga memiliki keajaiban, mampu berbicara ketika masih dalam buaian sebagaimana disebutkan dalam hadis Nabi Muhammad Saw. Dalam Shahîh $\underline{h}$ al-Bukhârî, ${ }^{6}$ disebutkan riwayat sebagai berikut:

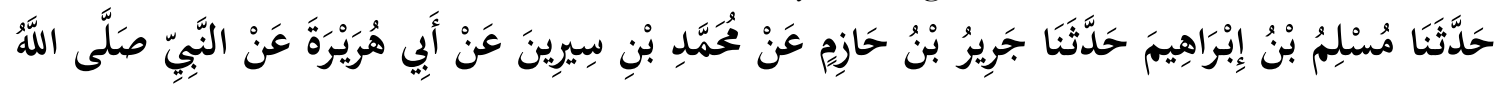

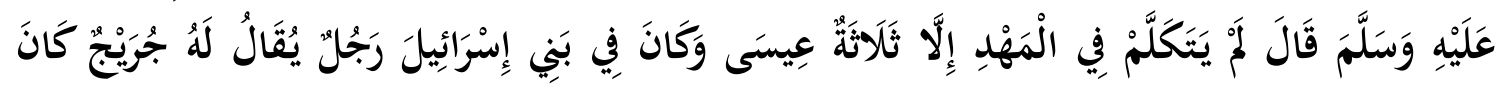

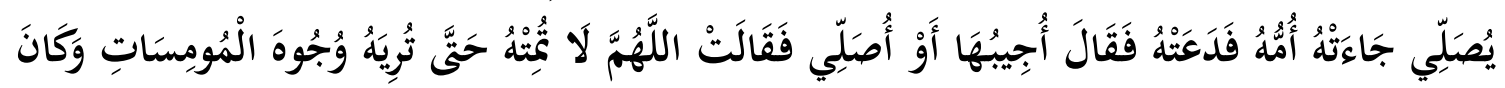

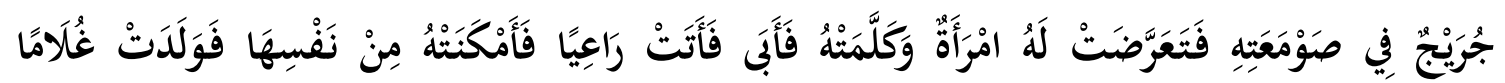

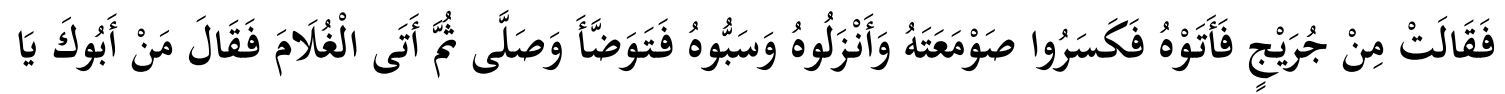

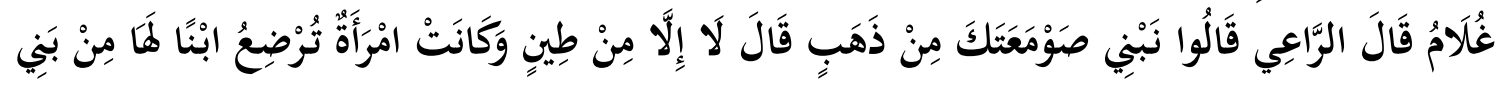

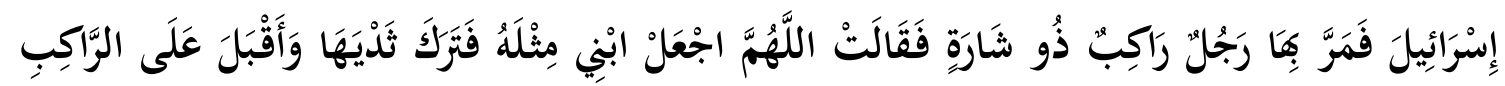

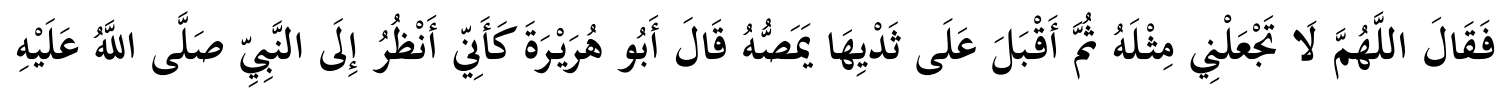

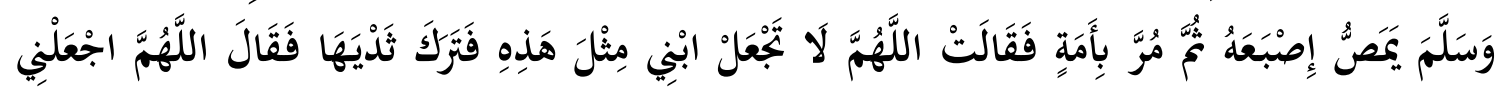

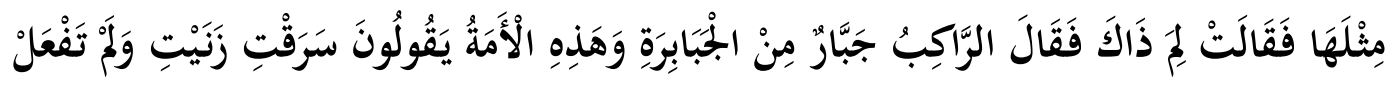
Imam al-Bukhari selaku periwayat hadis menyatakan, "telah berbicara kepada kami Muslim bin Ibrabim, ia menyatakan telah berbicara kepada kami Jarir bin Hẫim, dari Muhammad bin Sirîn, dari

${ }^{6}$ Baca dalam Shahîh $\underline{h}$ al-Bukhârî, kitab Âhâdîts al-Anbiyâ, bab Qaul Allah Udžkur fì Kitâb Maryam, hadis nomor 3181, Shahîh Muslim, kitab al-Birru wa al-Shilah wa al-Âdâb, bab Taqdimu Birr al-Walidain, hadis nomor 4626. 
Abu Hurairah, dari Nabi Saw., Beliau bersabda, "Tidak ada yang berbicara ketika dalam buaian kecuali tiga orang, yaitu: -Pertama- 'Isâ, putera Maryam, -Kedua- seorang laki-laki dari Bani Isrầîl, yang dipanggil dengan nama Juraij. Suatu ketika, ia (Juraij) sedang shalat, ibunya datang memanggilnya. Juraij ragu apakah memenubi panggilan ibunya atau tetap shalat. - Akbirnya, ia memilih tetap shalat, ibunya pun kecewa dan - mendoakannya, "Ya Allah jangan kau matikan ia (Juraij) sehingga engkau perlibatkan kepadanya muka orang-orang yang suka berzina." Manakala Juraij berada dalam biaranya, datang seorang perempuan dan berusaha meraynny, namun Juraij menolaknya. Perempuan itu pun pergi menemui seorang penggembala dan berbasil meraynnya sehingga ia akbirnya bunting dan melabirkan seorang anak yang ia akui sebagai anak dari Juraij. Orang-orang pun marah dan menghancurkan biara, tempat tinggal Juraij. Mereka mengusir dan memaki-maki Juraij. Juraij pun berwndhu dan shalat, kemudian ia mendatangi anak laki-laki dari perempuan tersebut dan bertanya, "siapa ayahmu?" Anak itu pun menjawab, "Seorang penggembala". Orang-orang pun berkata, kami akan membangunkan kembali biaramu dari emas, namun Juraij menolaknya, ia hanya ingin biara yang terbuat dari tanah seperti sebelumnya. -Ketiga- seorang perempuan yang sedang menyusui anak laki-lakinya di zaman bani Isra il, ketika itu lewat di hadapannya seorang laki-laki pejabat dengan kendaraannya. Sang ibu pun berdo'a, Ya Allah jadikanlah anakeku ini seperti laki-laki tersebut. Sang anak yang sedang menyusu, seketika berbenti menyusu dan melepaskan puting susu sambil berkata, Ya Allah jangan jadikan aku seperti laki-laki itu. Kemudian, sang anak kembali mengbisap puting susu ibunya,dengan dalam susuan. Abu Hurairah berkata, seakan-akan aku melihat Rasulullah menghisap-bisap ujung jari tangannya. Kemudian, lewat di depan ibu tersebut seorang perempuan jelata. Sang ibu pun berdoa, Ya Allah jangan Kau jadikan anakku seperti perempuan itu. Anak itu pun kembali melepaskan puting susu ibunya dan berkata, Ya Allah jadikanlah aku seperti perempuan itu. Sang ibu pun beran dan bertanya, kenapa begitu? Sang anak menjawab, laki-laki itu adalah seorang pejabat yang sombong, sedangkan perempuan jelata itu, ia ditudub orang sebagai seorang penzina padahal ia tidak pernah melakukannya."

Namun demikian, yang menjadi fokus perhatian dalam hal ini bukanlah tentang keajaiban bayi-bayi tersebut melainkan tentang penggunaan buaian atau ayunan yang sudah dikenal sejak zaman bayi-bayi itu ada. Sebagaimana disinggung sebelumnya, selain sebagai alat untuk menidurkan bayi, ayunan juga terkadang digunakan sebagai alat bermain oleh anak-anak sejak zaman dahulu. Hal ini dapat diketahui dari informasi dalam beberapa riwayat hadis Nabi Muhammad Saw., yang mendeskripsikan tentang usia dan perilaku 'Aisyah ra., ketika dinikahi oleh Muhammad Saw., disebutkan bahwa 'Aisyah ra., ketika itu masih berusia enam tahun dan masih senang bermain ayunan bersama teman-teman

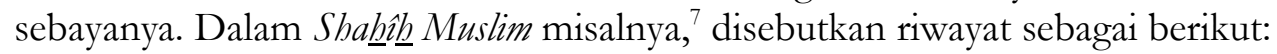

${ }^{7}$ Shabîh Muslim, kitab al-Nikâh, bab Tazwîj Abi Bakr al-Shaghîrah, hadis nomor 2547; lihat juga dalam Shahîh al-Bukhâri, kitab al-Manaqib, bab Tazwîj al-Nabiy 'Aisyah hadis nomor 3605; dan Sunan Abî Daûd, kitab al-Adab, bab Fî al-Urjūbah, hadis nomor 4285. 


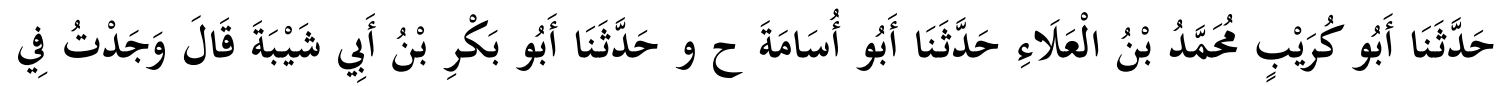

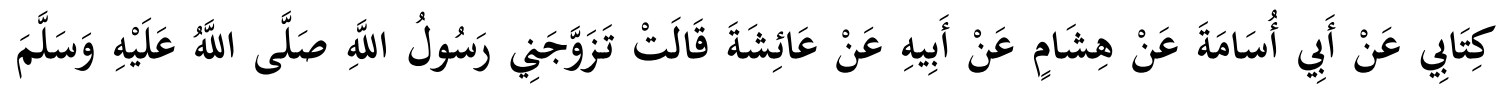

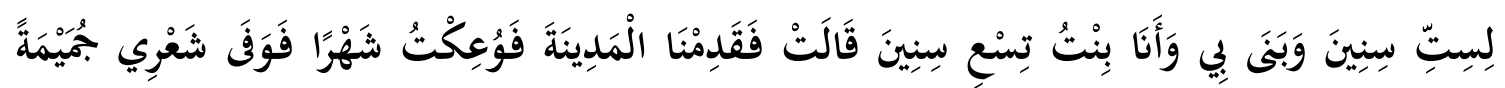

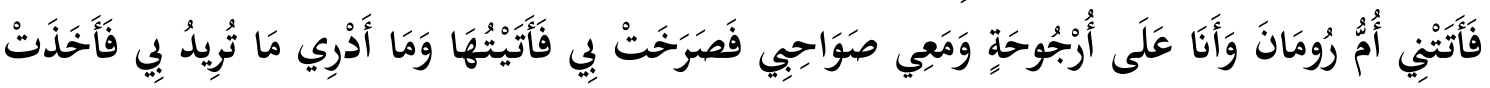

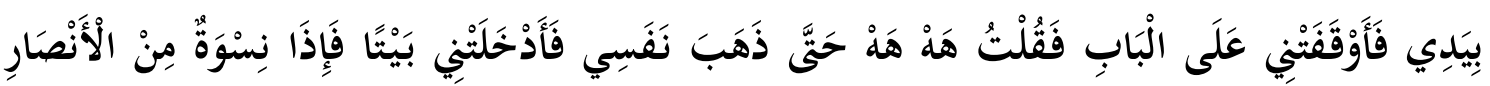

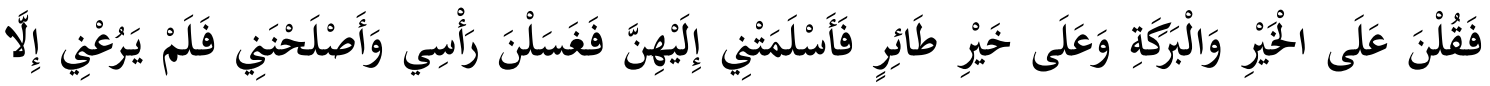

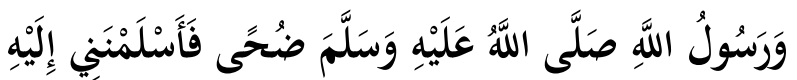

Imam Muslim meriwayatkan, telah berbicara kepada kami Abu Kuraib, Muhammad bin al-'Ala, ia menyatakan telah berbicara kepada kami Abu Usâmah dan telah berbicara juga kepada kami Abu Bakr bin Abi Syaibah ia berkata, aku menemukan dalam kitabku sebuah keterangan dari Abi Usamah dari Hisyam dari Ayahnya dari 'Aisyah, ia berkata, Rasulullah Saw. telah menikabiku ketika aku berusia 6 tahun dan membina rumah tangga denganku ketika aku berusia 9 tabun. Ketika kami datang ke Madinah, aku sakit selama satu bulan sehingga rambut di kepalaku rontok. Ummu Rumman (Isteri Abu Bakr) mendatangiku ketika aku sedang bermain ayunan bersama beberapa orang sababatku. Ia berteriak memanggilk.u, aku pun mendatanginya. Aku tidak mengetabui apa yang dïnginkannya, ia menarik tanganku dan membawaku sampai di depan pintu. Aku hanya berkata, "bah," "bah," Ia (Ummu Rumman) memasukkanku ke dalam sebuah rumah yang di dalamnya sudah ada beberapa orang perempuan dari kaum Anshar. Mereka berkata, Semoga engkau dalam kebaikan dan keberkahan. Ummu Rumman menyerabkanku kepada mereka dan mereka pun membasub kepalaku dan mendandaniku kemudian mereka menyerabkanku kepada Rasulullah."

Fokus perhatian dalam riwayat tersebut adalah istilah "Urjübah," dalam kitab 'Aun alMa'bûd Syarb Sunan Abî Daûd dijelaskan maknanya sebagai sepotong kayu atau balok yang diikat kedua sisinya dengan tali dan digantung pada tempat yang tinggi, kemudian seorang anak naik atau duduk di atas kayu tersebut sambil bergerak berayun-ayun. Ringkasnya dapat disimpulkan bahwa ayunan sudah dikenal dan digunakan sejak zaman dahulu, baik sebagai alat untuk menidurkan bayi maupun alat bermain bagi anak-anak.

\section{Tradisi Baayun Anak dalam Masyarakat Banjar}

Dalam praktik hidup keseharian, suku Banjar yang mayoritas beragama Islam tidak terlepas dari tradisi nenek moyang mereka. Tradisi nenek moyang ini tetap diaktualisasikan oleh masyarakat Banjar dalam berbagai sendi kehidupan dengan tingkat intensitas yang beragam seiring dengan tingkat pemahaman keberagamaan, penguasaan ilmu pengetahuan, dan pengaruh perkembangan zaman. Tidak terkecuali dalam hal tradisi baayun anak, dalam 
masyarakat Banjar, di rumah-rumah mereka yang memiliki bayi masih sangat mudah dijumpai ayunan-ayunan dengan berbagai model, mulai dari model ayunan yang sederhana, yang hanya terdiri dari selembar kain yang kedua ujungnya diikat dengan dua utas tali yang keduanya kemudian digantungkan di tempat yang tinggi, hingga model ayunan yang terbuat dari besi pegas, yang memungkinkan bebannya bergerak turun naik seperti diayun ke atas dan ke bawah. Beragam model ayunan ini memiliki fungsi yang sama, yaitu untuk membuai sang bayi agar cepat terlelap dan tidur dengan nyenyak. Sambil menggerakkan ayunan, sang ibu biasanya melantunkan sya'ir-sya'ir, baik berupa shalawat atas Nabi Muhammad Saw. maupun nyanyian yang berisi harapan-harapan kebaikan bagi masa depan si anak, atapun dibacakan ayat-ayat Alquran, zikir dan lain-lain.

Bagi orang Islam, peringatan maulid Nabi biasanya dimaksudkan untuk mengenang kembali peristiwa bersejarah lahirnya Nabi Muhammad Saw., seorang tokoh besar pembawa risalah ilahi yang segala sisi dari hidup dan kehidupannya mengandung 'ibrah dan merupakan teladan dalam mencapai kebahagiaan hidup di dunia dan di akhirat. Bagi seorang muslim, memperingati maulid Nabi Muhammad Saw. merupakan sebuah ekspresi keberagamaan, mulai dari rasa syukur atas kehadiran seseorang yang sangat berjasa; pembawa cahaya petunjuk dari "alam kegelapan ke alam yang terang-benderang," hingga rasa cinta kepada sosok sang pembawa risalah yang memiliki akhlak dan budi pekerti utama. Berawal dari ekspresi tersebut, seorang muslim biasanya berharap mendapat keberkahan hidup di dunia dan syafa'atnya di hari akhir nanti. Sedangkan dari ekspresi rasa cinta terhadap sosok sang Nabi, seorang muslim biasanya berharap dapat meneladani akhlak mulia dari sang idola.

\section{Pelaksanaan Upacara Baayun Mulud di Banjarmasin}

1. Kecamatan Banjarmasin Utara

Baayun Mulud adalah acara tradisi mengayun anak ataupun orang yang telah dewasa, yang dilaksanakan dalam acara peringatan maulid Nabi Muhammad Saw., pada tanggal 12 Rabî al-Awwal tahun Hijriyyah, di depan makam raja kerajaan Banjar yang pertama, yaitu Sultan Suriansyah, yang berlokasi di Kelurahan Kuin Utara Kecamatan Banjarmasin Utara kota Banjarmasin Provinsi Kalimantan Selatan. Baayun mulud ini juga tradisi lama yang selalu digelar oleh keturunan raja Banjar.

Acara baayun mulud ini pada awalnya sangat erat kaitannya dengan acara bapalas bidan. Seorang bayi yang baru lahir dinyatakan sebagai anak bidan sampai dilaksanakan upacara bapalas bidan, suatu upacara pemberkatan yang dilakukan oleh bidan kampung terhadap si bayi dan ibunya. Upacara ini tetap diselenggarakan walau kelahiran bayi mendapat bantuan dari bidan yang berpendidikan atau dokter rumah sakit. Apabila acara tidak dilakukan konon bisa menyebabkan bayi sering sakit karena diganggu makhluk gaib.

Dalam upacara bapalas bidan ini disediakan ayunan (buaian) yang terdiri tiga lapis kain panjang, lapis yang paling atas biasanya berwarna kuning. Juga disediakan berbagai kue-kue 
dan piduduk, baik piduduk kering maupun piduduk basah, dan berbagai peralatan-peralatan lainnya. Seorang bayi pertama-tama harus diayun (dibuai) oleh bidan, dalam acara bapalas bidan ini. Dan sampai sekarang nampaknya sebagian bayi-bayi di Kalimantan Selatan tidak bisa dilepaskan dengan ayunan (buaian), baik mereka di ayun atau dipukung

Pada perkembangan berikutnya untuk daerah ini, acara bapalas bidan dilakukan bersamaan waktunya dengan acara peringatan hari kelahiran Nabi Muhammad Saw., sehingga penggabungan acara bapalas bidan dengan peringatan hari kelahiran Nabi dilakukan dengan bersama-sama dalam waktu dan tempat yang sama pula. Sehingga lahir istilah baayun mulud. Yakni mengayun anak pada bulan Maulid, yang memiliki tujuan dan kepercayaan tersendiri, Dan berbagai tradisi serta peralatan dan sesajen pada acara bapalas bidan tetap dipertahankan dalam pelaksanaan baayun mulud ini. Upacara baayun mulud ini sebuah tradisi yang merupakan hasil akulturasi budaya yang digelar oleh mereka yang pada mulanya merasa keturunan raja. Namun tradisi ini telah lama sudah tenggelam atau tidak dilaksanakan, dan baru sekitar tujuh tahun terakhir ini dihidupkan kembali ${ }^{8}$.

Acara baayun mulud sebenarnya telah menjadi tradisi yang biasa dilakukan oleh masyarakat muslim yang tinggal di kota Banjarmasin. Tradisi ini memang lebih banyak dilakukan oleh masyarakat Banjar, khususnya di lingkungan masyarakat Banjar Kuala, yaitu orang Banjar yang tinggal di wilayah Banjarmasin, Marabahan, Martapura, hingga Rantau. Sedangkan masyarakat Banjar Pahuluan, yaitu orang Banjar yang umumnya tinggal di wilayah hulu sungai, jarang melakukan tradisi serupa.

Karena kegiatan ini membutuhkan biaya yang relatif banyak, acara ini biasanya hanya dilakukan secara perorangan oleh mereka yang tergolong mampu secara ekonomis. Khusus di kawasan Banjarmasin Utara, penyelenggaraan acara ini secara massal baru diadakan dalam sepuluh tahun terakhir. Hal ini, selain untuk membantu mereka yang tidak mampu menyelenggarakannya secara perorangan, menurut H. Ahmad Yamani, ketua panitia penyelenggara bertujuan untuk "menimbulakan batang nang tinggalam"'. Artinya, sebagai upaya untuk menghidupkan kembali tradisi yang pernah berkembang di tengah-tengah masyarakat Banjar sejak dahulu, yakni sejak masih berkuasanya kerajaan Banjar.

Panitia penyelenggara kegiatan, selain beranggotakan mereka yang memang seharihari bertugas sebagai pengurus makam Sultan Suriansyah-yang pada umumnya merupakan keturunan dari Raja Banjar-dibantu juga oleh warga masyarakat yang bertempat tinggal di sekitar makam, dan dibantu oleh aparat Kelurahan Kuin Utara, aparat Kecamatan 2011.

${ }^{8}$ Wawancara pribadi dengan H. Burhan (pengurus makam pangeran Suriansyah )pada tanggal 5 Juni

${ }^{9}$ Wawancara langsung pada waktu pelaksanaan kegiatan Baayun mulud hari Selasa, 15 Februari 2011/12 Rabî al-Awwal 1432 di depan makam Sultan Suriansyah Kelurahan Kuin Utara Kecamatan Banjarmasin Utara Kota Banjarmasin Provinsi Kalimantan Selatan. 
Banjarmasin Utara dan aparat Kepolisian Sektor Banjarmasin Utara. Fungsi panitia secara khusus adalah untuk mendatangkan mereka yang bertugas melantunkan sya'ir maulid ini dari kelompok yang memang terbiasa melakukannya. Panitia mengaku kesulitan untuk mencari mereka yang mampu melakukan hal ini karena relatif mulai langka keberadaannya di Banjarmasin dan sekitarnya.

Peserta yang hadir mendengarkan ceramah terdiri dari berbagai lapisan masyarakat termasuk aparat pemerintah, mulai dari perwakilan pemerintah provinsi Kalimantan Selatan, wakil walikota Banjarmasin, aparat keamanan dari Poltabes dan Kodim, juga dari kantor urusan agama kecamatan Banjarmasin Utara. Di samping banyaknya perserta yang ikut acara baayun mulud.

Acara maayun mulud yang diselenggarakan di depan makam Pangeran Sultan Suriansyah ini pada mula hanya terbatas hanya untuk keluarga bububan (keturunan kerajaan). Namun sekarang sudah terbuka untuk umum, yaitu siapa saja yang ingin menjadi peserta, walaupun dari luar daerah dan dari suku apa saja bila berkeinginan dan mendaftarkan diri sebagai peserta akan diterima. Adapun peserta untuk tahun 2011 berjumlah 117 orang dari berbagai latar belakang. Menurut ketua panitia penyelenggara, H. Ahmad Yamani, sebenarnya peserta yang berminat untuk mengikuti kegiatan ini jauh melebihi jumlah tersebut, namun karena keterbatasan tempat kegiatan, maka panitia terpaksa membatasi jumlah mereka yang mendaftar sebagai peserta, dan sangat banyak yang tidak bisa diterima sebagai peserta. Hal ini bisa dimaklumi, karena fasilitas ayunan (buaian) yang disediakan panitia dengan luas sekitar 1,25 meter persegi untuk masing-masing peserta, terlihat begitu sesak ketika di bawahnya digunakan oleh masing-masing peserta untuk meletakkan "piduduk" dan sesajen lainnya dan dikerumuni pula oleh sanak famili dan kerabatnya masingmasing.

Dilihat dari usia peserta yang diayun, mayoritas berusia balita dari bayi yang baru lahir hingga usia taman kanak-kanak. Hanya beberapa di antaranya yang berusia dewasa, persisnya 3 orang nenek-nenek, berusia sekitar 50 hingga 60 tahun. Kemudian, dilihat dari asal daerah, acara Baayun Mulud di tempat ini diikuti terutama oleh mereka yang bertempat tinggal di sekitar lokasi kegiatan. Selain itu terdapat pula beberapa peserta yang berasal dari luar wilayah kota Banjarmasin. Yaitu dari Kapuas, Anjir dan Batulicin. ${ }^{10}$

Masyarakat sekitar makam sultan suriansyah secara umum tampak jelas memberikan dukungan bagi kegiatan baayun mulud ini. Hal ini ditunjukkan baik dari antusiasme mereka sebagai peserta kegiatan, maupun dukungan mereka secara bersama-sama bergotong-royong mempersiapkan segala sesuatu yang terkait dengan suksesnya acara peringatan maulid Nabi Besar Muhammad Saw. dan kegiatan baayun mulud seperti mendirikan tenda, membuat tiang-

${ }^{10}$ Wawancara pribadi dengan H. Ahmad Yamani (Ketua Panitia penyelenggra) pada 15 Juni 2011 
tiang ayunan, serta menyediakan konsumsi untuk tamu undangan dan hadirin yang menghadiri peringatan maulid Nabi.

Dari aparat pemerintah, baik yang mewakili pemerintah provinsi Kalimantan Selatan maupun kota Banjarmasin terlihat memberikan dukungan penuh dan sangat mengapresiasi kegiatan Baayun mulud ini. Kegiatan ini direncanakan akan menjadi event wisata budaya yang akan digelar setiap tahun.

Untuk peserta Baayun Mulud, panitia sengaja mendirikan tenda besar di atas tanah kosong di halaman depan makam Sultan Suriansyah. Ukuran tenda yang didirikan dengan tiang besi dan atap terpal tersebut tidak kurang dari 25 X 20 meter persegi. Sebagian perlengkapan yang digunakan untuk acara Baayun Mulud disediakan oleh panitia dengan menggunakan dana dari uang pendaftaran dari peserta. Sebagian lagi dibawa dan ditambahkan oleh peserta masing-masing. Adapun peralatan yang telah disiapkan atau disediakan oleh panitia, terdiri dari:

a. Tiang kayu yang kokoh untuk mengantung ayunan (buaian).

b. Tali tambang sebagai tali ayunan.

c. Empat lembar kain (terdiri dari 1 lembar kain sarung batik, 3 lembar kain aksesoris berwarna kuning dan hijau). Sebagai tempat peserta yang ikut acara baayun mulud

d. Aksesoris ayunan berupa anyaman-anyaman dari daun nipah yang dibentuk burungburung, halilipan, ular-ularan, rantai, ketupat dan lain-lain. ${ }^{11}$

Sedangkan peralatan yang harus disiapkan dan dibawa sendiri oleh peserta adalah:

a. Piduduk", yaitu berupa sesajen yang disiapkan oleh peserta, umumnya berupa beras, buah kelapa, dan gula merah, jarum, benang, uang logam, selebihnya bervariasi sesuai kepercayaan. Adapun makna simbolik yang terkandung dalam benda-benda yang disediakan oleh seorang peserta. Piduduk ini diletakkan dalam satu tempat khusus yang disebut sasanggan (bokor). Terkadang benda-benda perlengkapan atau peralatan ini disebut dengan istilah piduduk kering.

b. Makanan (nasi ketan, telor bebek, bubur merah, bubur putih, dll) dan kue-kue di antaranya ialah kue apam, cucur, cincin, cingkarok, dll . Benda yang berupa jenis makanan ini terkadang bisa disebut piduduk basah.

c. Uang kertas yang difotokopi dengan ukuran besar dengan jumlah bervariasi yang digantung melengkapi aksesoris ayunan.

d. Buah-buahan yang juga digantung sebagai aksesoris ayunan. Di antara buah-buahan itu ialah jambu, salak, jeruk, apel dan lain-lain.

e. Daun-daunan. ${ }^{12}$

11Wawancara Pribadi dengan H. Burhan pada tanggal 12 Juni 2011.

12Wawancara pribadi dengan Badruzzaman pada tanggal 15 Juni 2011. 
Ada tiga acara utama yang diselenggarakan dalam rangkaian peringatan maulid Nabi Besar Muhammad Saw. Ketiga acara tersebut adalah: Pertama, pembacaan sya'ir-sya'ir maulid. Kedua, kegiatan baayun mulud. Ketiga, ceramah agama sekitar maulid Nabi Muhammad Saw. Acara pertama dan kedua dilakukan secara bersamaan. Setelah selesai keduanya, kemudian disusul acara ketiga sebagai puncak kegiatan.

Penceramahnya adalah K.H. Ali Furqan. Sedangkan yang hadir mendengarkan ceramah terdiri dari berbagai lapisan masyarakat termasuk aparat pemerintah, mulai dari perwakilan pemerintah provinsi Kalimantan Selatan, Wakil Walikota Banjarmasin, aparat keamanan dari Poltabes dan Kodim, juga dari kantor urusan agama kecamatan Banjarmasin Utara.

Acara dimulai sekitar pukul 8 pagi, dengan pembacaan sya'ir-sya'ir maulid syarafal anam $^{13}$. Seiring dengan itu, semua peserta yang pada umumnya bayi dan anak-anak telah mulai dimasukkan ke dalam ayunan dan mulai diayun seakan dibuai untuk ditidurkan. Menurut panitia, waktu yang paling baik untuk mengayun bayi ini, sebenarnya tepat pada saat-saat pembacaan sya'ir asyrakal (karena adanya kepercayaan di sebagian masyarakat Banjar bahwa ketika sya'ir asyrakal itu dibacakan, ruh Rasulullah Saw., hadir di tengah-tengah kumpulan orang yang membacanya).

Diawal acara, bayi atau anak-anak dalam ayunan diayun, sebagian anggota keluarga menambahkan pernak-pernik aksesoris pada ayunan. Sedang sebagian lainnya, menyusun dengan rapi "piduduk" (sesajian) di bawah ayunan yang ditempati anggota keluarganya. Baik bayi atau anak, maupun orang dewasa yang berada dalam ayunan terus diayun selama pembacaan sya'ir maulid hingga akhir pembacaan sya'ir 'asyraqal. Setelah pembacaan sya'ir asyraqal berakhir, semua pernak-pernik aksesoris yang digantung pada ayunan demikian pula sesajian yang dihamparkan di sekitar ayunan, menjadi sesuatu yang diperebutkan oleh anggota keluarga yang sedari awal telah berkerumun di sekitar ayunan.

Selesai acara pembacaan sya'ir-sya'ir maulid dan baayun mulud, acara dilanjutkan dengan ceramah agama sekitar maulid Nabi Muhammad Saw. Acara ceramah agama ini diawali dengan pembukaan dan pembacaan ayat-ayat suci al-Qur'ân, kemudian sambutan panitia pelaksana sekaligus pembacaan riwayat kerajaan Banjar, disusul kemudian dengan sambutan yang disampaikan langsung oleh Wakil Walikota Banjarmasin, Bapak H. M. Irwan

${ }^{13}$ Syarafal anam" adalah sebutan orang Banjar untuk nama kumpulan sya'ir-sya'ir maulid syarf alanâm (manusia yang mulia), yang di samping berisi pujian-pujian bagi Nabi Muhammad Saw., juga berisi uraian tentang sîrah al-nabawiyyah (perjalanan hidup kenabian) yang penuh dengan kemuliaan, hikmah, dan keteladanan. Ada 3 jenis sya'ir maulid yang biasanya dilantunkan masyarakat Banjar ketika memperingati maulid Nabi Muhammad Saw. Ketiga jenis sya'ir maulid tersebut adalah: 1) Syarafal anam (syarf al-anâm) 2)

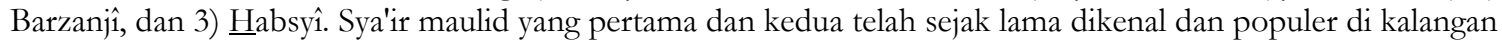
masyarakat Banjar, sedangkan yang terakhir mulai populer sejak awal tahun 90 -an. Persisnya sejak ditradisikan oleh ulama kharismatik asal Martapura, Kalimantan Selatan, K.H. Muhammad Zaini bin Abdul Ghani (w. 2005) di dalam pengajiannya di mushalla Ar Raudhah, Sekumpul, Martapura. 
Anshari. Kemudian, sambutan dari Gubernur Kalimantan Selatan. Karena bertepatan dengan hari pelaksanaan kegiatan ini, Gubernur menghadiri acara yang lebih penting, maka sambutan tertulis dari Gubernur dibacakan oleh kepala dinas pariwisata Provinsi Kalimantan Selatan. Setelah mendengari berbagai sambutan, acara dilanjutkan dengan mendengarkan ceramah agama yang disampaikan oleh Ustadz H. Ali Furqan.

Dengan gayanya yang kocak, Ustadz H. Ali Furqan menyampaikan ceramah. Inti dari isi ceramahnya adalah bagaimana agar umat Islam mencintai Rasulullah Saw. dan berusaha meneladani akhlaknya yang mulia. Selesai ceramah agama, acara ditutup dengan do'a yang dipimpin oleh Ustadz H. Ali Furqan. Kemudian, panitia membagikan konsumsi berupa nasi kotak untuk seluruh hadirin. Karena begitu banyaknya jumlah anggota masyarakat yang menghadiri acara ini, jumlah 1000 nasi kotak yang dibagikan panitia masih tidak mencukupi untuk keseluruhan anggota masyarakat yang hadir dalam acara tersebut ${ }^{14}$.

Penyelenggaraan kegiatan baayun mulud pada tahun 2011 ini sepertinya sama sekali tidak menghadapi kendala yang berarti. Satu-satunya kendala yang diungkapkan oleh ketua panitia penyelenggara, Bapak H. Ahmad Yamani adalah sempitnya lahan yang dapat digunakan sebagai lokasi mendirikan tenda untuk acara baayun mulud. Kecilnya lahan ini tidak sebanding dengan besarnya minat anggota masyarakat untuk menjadi peserta, sehingga panitia terpaksa membatasi jumlah pendaftar yang berminat.

Adapun tantangan dalam bentuk penolakan terhadap penyelenggaraan acara baayun mulud ini tidak tampak sama sekali. Justru sebaliknya, acara ini mendapat dukungan dari berbagai pihak dan instansi pemerintahan.

\section{Kecamatan Banjarmasin Tengah}

Kegiatan baayun mulud sebagai rangkaian acara peringatan maulid Nabi Besar Muhammad Saw. di kota Banjarmasin telah diselenggarakan di beberapa tempat. Selain di Makam Sultan Suriansyah yang berada di wilayah kecamatan Banjarmasin Utara, di beberapa buah mesjid yang ada di wilayah kota Banjarmasin juga menggelar acara serupa, bahkan di salah satu hotel berbintang.

Adapun untuk wilayah kecamatan Banjarmasin Tengah, penyelenggaraan kegiatan yang relatif besar diadakan di Mesjid Jami' Teluk Dalam. Diadakannya kembali kegiatan baayun mulud pada tahun ini, menurut $\mathrm{H}$. Risfani, tidak lain adalah untuk menyemarakkan peringatan maulid Nabi Besar Muhammad Saw. selain juga untuk menghidupkan kembali tradisi yang telah lama berkembang di kalangan masyarakat Banjar serta dalam rangka menjalin sulaturrahim.

Baayun mulud di mesjid Jami' Teluk Dalam sudah pernah dilaksanakan pada tahun 2003 M pada saat dikelola oleh Abdul Hadi (anggota DPR). Selama tiga tahun berturut-

${ }^{14}$ Wawancara pribadi dengan Amang Tiak pada tanggal 5 Juni 2011. 
turut, kemudian terhenti selama lima tahun, dari tahun 2005 sampai dengan tahun 2010 hal ini disebabkan panitia mesjid saat itu tidak merespon terhadap acara baayun mulud ini. Kemudian kepanitiaan mesjid berganti sejak 01 Januari 2011 yang diketuai oleh guru Imberan, dan kini dihidupkan kembali tradisi ini yang telah diprakarsai oleh Bapak H. Risfani, sehingga pada tanggal 17 Rabiul Awal 1432 H. atau tanggal 20 Pebruari 2011 M. digelar kembali acara baayun mulud ini. Bapak H. Risfani mengaku dia keturunan orang Rantau yang selalu melaksanakan baayun mulud sejak dulu dari datuk neneknya. Lebih jauh diungkapkannya, sebenarnya acara ini direncanakan pada tanggal 12 Rabiul Awal tahun 1432 H. Namun berhubung penceramah yang direncanakan berhalangan yakni bersamaan jadwalnya dengan ceramah pada acara baayun mulud di Rantau, sehingga untuk di mesjid Jami' diadakan penundaan ${ }^{15}$.

Menurut koordinator panitia pelaksana, Bpk H. Rifani, diakui memang bahwa panitia kegiatan baayun mulud di Mesjid Teluk Dalam untuk tahun 2011 ini tampak kurang mantap melakukan persiapan. Sebab kegiatan ini hanya disiapkan dalam waktu 20 hari saja, padahal seharusnya persiapan selama 40 hari sebelum acara dilaksanakan, dan panitia tidak menduga akan besarnya antusias warga untuk mengikuti kegiatan ini.

Yang bertugas sebagai panitia penyelenggara kegiatan baayun mulud pada umumnya sekaligus merupakan pengurus mesjid Jami' Teluk Dalam. Bapak H. Risfani yang bertindak sebagai koordinator panitia pelaksana, merupakan anggota pengurus Mesjid Jami' Teluk Dalam periode sekarang ini. Beliau mengaku keturunan pemilik tanah waqaf untuk lokasi mesjid Jami' ini didirikan. Beliau berasal dari Rantau, menurut beliau, selama bertugas di Dinas Pariwisata Kabupaten Tapin selalu terlibat langsung dalam kepanitiaan pada acara baayun mulud di daerah Banua Halat Kabupaten Tapin Provinsi Kalimantan Selatan. Sebagaimana dimaklumi bahwa acara baayun mulud di daerah ini telah sejak lama diadakan dan setiap tahunnya selalu diikuti oleh ratusan bahkan pada tahun 2011 ini mencapai seribu lebih peserta.

Dalam rangka persiapan penyelenggaraan kegiatan baayun mulud di mesjid Jami' Teluk Dalam pada tahun 2011 ini, panitia telah memasang beberapa spanduk pengumuman pemberitahuan kegiatan di beberapa sudut kota Banjarmasin. Panitia juga membuka sekretariat pendaftaran di sebuah warnet milik H. Risfani yang berada tepat sebelah kanan mesjid Jami' Teluk Dalam.

Adapun acara baayun mulud di mesjid Jâmi' Teluk Dalam, diselenggarakan pada hari Minggu tanggal 17 Rabî' al-Awwal 1432 H/20 Februari 2011. diikuti oleh 85 orang peserta. Dilihat dari segi usia peserta, mayoritas peserta merupakan anak-anak usia balita. Peserta tertua adalah seorang anak berusia sekitar 13 tahun duduk di kelas 1 SMP. Sedangkan dilihat dari asal daerah dan asal-usul kesukuan peserta, ternyata acara baayun mulud ini tidak saja

15Wawancara Pribadi dengan Risfani pada tanggal 12 Juni 2011. 
diikuti oleh mereka yang berasal dari suku Banjar, tetapi juga diikuti oleh beberapa peserta yang berasal dari suku Jawa. Kesemua peserta merupakan warga Kota Banjarmasin yang bertempat tinggal di sekitar mesjid Jami'.

Berbeda halnya dengan pelaksanaan baayun mulud di depan makam Sultan Suriansyah, kegiatan baayun mulud di Mesjid Jami' Teluk Dalam ini diadakan di dalam ruang utama mesjid sehingga panitia penyelenggara tidak lagi direpotkan dengan urusan mendirikan tenda. Panitia menyiapkan tiang-tiang ayunan yang terbuat dari kayu balok, tali ayunan, sarung batik dan 3 lembar kain berwarna kuning, hijau dan putih. Aksesoris ayunan berupa anyam-anyaman dari daun kelapa yang dipesan langsung dari kampung Baru Banjarmasin, sebuah kawasan yang terkenal sebagai sentra kerajinan anyaman ketupat. Satu perangkat piduduk (sesajian) untuk keseluruhan peserta.

Adapun berbagai perlengkapan / peralatan yang disediakan oleh panitia untuk lebih jelasnya adalah:

a. Kain tiga lapis untuk peserta yang di ayun.

b. Tali, yang digunakan untuk menggantung kain ayunan.

c. Tiang, yang bergunan untuk mengikat tali dan berbagai hiasan-hiasan.

d. Tapung Tawar yang terdiri dari air doa, mangkuk, daun pisang dll.

e. Piduduk, yang merupakan persyaratan acara baayun mulud, yang terdiri :

1) Piduduk kering yang meliputi: beras, gula merah, uang, benang, jarum, kelapa, telor, beras ketan.

2) Piduduk basah meliputi bermacam-macam kue seperti apam, cucur, cincin, kokoleh, ketupat, nasi ketan, tape, cingkaruk dan lain-lain ${ }^{16}$

Adapun dana dihimpun melalui sumbangan dari peserta sebesar Rp 125.000,-. Uang tersebut digunakan Rp 120.000 untuk pembelian perlengkapan ayunan seperti dua lembar kuning dan hijau, kain batik satu lembar dan tali serta pembelian piduduk dan Rp 5.000 untuk pembelian tiang ayunan (bambu). Di samping sumbangan dari setiap peserta, juga ada mendapat bantuan dari pemerintah daerah sebesar Rp 2.000.000,-- Semua dana tidak dipungut untuk mesjid maupun untuk panitia.

Dalam suasana udara dingin kota Banjarmasin karena telah diguyur hujan pada malam harinya, di pagi hari minggu tanggal 17 Rabi'ul Awwal 1432 H/20 Februari 2011, diiringi dengan rintik-rintik gerimis sekitar pukul 07.00 pagi para peserta baayun mulud sudah mulai bersiap-siap di mesjid Jami' Teluk Dalam Banjarmasin Tengah. Kebanyakannya kaum ibu bersama anggota keluarganya yang akan diayun sudah mulai berkumpul di sekitar ayunan masing-masing. Panitia penyelenggara sudah menuliskan nama masing-masing peserta pada 
ayunan yang telah disiapkan. Tiang ayunan sengaja dibuat dari kayu kaso yang kokoh ukuran $5 \times 7 \mathrm{~cm}$ sehingga dapat digunakan untuk kegiatan serupa pada tahun-tahun berikutnya.

Ruang tengah mesjid digunakan untuk memancang tiang-tiang ayunan ini sehingga mampu menampung 85 orang peserta bersama masing-masing anggota keluarganya yang bertugas menggerakkan ayunan. Bagian dalam mesjid sebelah kiri digunakan sebagai tempat para petugas pembaca sya'ir maulid al-Habsyi, sedangkan pada bagian dalam mesjid sebelah kanan atau berhadapan dengan para pembaca sya'ir maulid, digunakan sebagai tempat duduk para hadirin dari kaum laki-laki. Kaum ibu ditempatkan secara terpisah dari kaum laki-laki. Kaum ibu menempati bagian tengah mesjid di belakang tempat ayunan. Adapun sekitar penceramah, para ulama dan tokoh masyarakat, ditempatkan baayun mulud.

Sekitar pukul 08.00 pagi, para petugas pembaca sya'ir maulid sudah mulai melantunkan sya'ir-sya'ir maulid al-Habsyi dan membacakan rawinya. Hadirin dan hadirat terlihat dengan khusyu menyimak lantunan sya'ir-sya'ir maulid yang dibawakan sambil sesekali menyahut/mengikuti bacaan sya'ir maulid yang dilantunkan. Seiring dengan pembacaan sya'ir-sya'ir maulid ini, para peserta baayun mulud yang pada umumnya adalah balita mulai diayun oleh ibu-ibunya.

Anehnya, meskipun hampir 1 setengah jam pembacaan sya'ir-sya'ir maulid yang diiringi dengan acara baayun ini berlangsung, tidak terdengar suara tangisan para peserta yang puluhan di antaranya merupakan bayi-bayi yang berumur kurang dari satu bulan. Bayibayi tersebut tampak senang-senang saja menikmati lantunan sya'ir-sya'ir maulid yang dibacakan. Bahkan, beberapa di antaranya sampai tertidur di dalam ayunan.

Sampai pada ketika pembacaan sya'ir Asyraqal, seluruh hadirin dan hadirat berdiri tidak terkecuali kaum ibu yang bertugas mengayun anak-anak mereka. Selanjutnya, seorang ulama yang memakai serban dan baju gamis berdiri, kemudian berkeliling diikuti oleh beberapa orang tokoh masyarakat dengan dibantu seorang panitia yang bertugas mengangkat sebuah mangkok besar berisi air kembang berjalan mengitari seluruh peserta yang diayun. Ulama tersebut mengucapkan shalawat sambil memercikkan air kembang ke seluruh peserta yang berada dalam ayunan. Selesai memercikkan air kembang ke seluruh peserta baayun mulud, acara dilanjutkan dengan pembacaan do'a maulid sebagai penutup rangkaian pertama acara peringatan maulid Nabi Besar Muhammad Saw.

Berikutnya, sekitar pukul 09.30 acara dilanjutkan dengan ceramah agama sekitar maulid Nabi Besar Muhammad Saw. Sebelumnya, acara ini diawali dengan pembacaan ayatayat suci al-Qur'ân. Disusul dengan penyampaian sambutan berupa laporan dari panitia penyelenggara peringatan maulid Nabi Besar Muhammad Saw. mesjid Jami' Teluk Dalam. Kemudian memasuki acara puncak, berupa ceramah agama sekitar maulid Nabi Besar Muhammad Saw. yang disampaikan oleh K.H. Husin Nafarin, Lc., M.A. Dalam ceramahnya memaparkan tentang bagaimana menjadikan Rasulullah Saw. sebagai figur idola dengan meneladani akhlak-akhlaknya yang mulia dan agar sejak dini para orang tua memberikan 
keteladanan yang baik bagi anak-anak mereka. Sampai sekitar pukul 11.00 siang, ceramah pun berakhir, ditutup dengan do'a dari sang penceramah.

Menurut pengakuan H. Risfani sebagai pemakarsa dan koordinator kegiatan ini, bahwa panitia pelaksana baayun mulud tahun ini dipandang kurang begitu siap, sebab tidak sempat membuat ayunan besar dalam bentuk rumah Banjar yang dipasang di depan mesjid, yang disebabkan keadaan cuaca yang kurang mendukung yaitu terjadi hujan lebat dalam waktu yang cukup lama. Setiap upacara baayun mulud lazimnya ayunan besar ini selalu ada. Di sini tempat berayun para pejabat dan ada potografer khusus untuk mengabadikan siapa yang berkeinginan berfoto di tempat itu .

Koordinator panitia pelaksana, Bpk H. Risfani lebih jauh mengungkapkan bahwa, panitia kegiatan baayun mulud di Mesjid Teluk Dalam untuk tahun 2011 ini tampak kurang mantap melakukan persiapan, hal ini karena panitia tidak menduga besarnya antusias warga untuk mengikuti kegiatan ini. Di samping itu, karena kegiatan ini sempat terhenti beberapa tahun setelah terakhir diadakan pada tahun 2005. Terhentinya kegiatan ini selama beberapa tahun, menurutnya karena yang menjadi pengurus Mesjid Teluk Dalam pada periode tersebut kurang mendukung diadakannya acara ini.

\section{Tujuan dari Baayun Mulud di Banjarmasin}

Tujuan diadakannya kembali kegiatan baayun mulud pada tahun ini, menurut $\mathrm{H}$. Risfani, pertama adalah untuk menyemarakkan peringatan maulid Nabi Besar Muhammad Saw. Kedua, untuk menghidupkan kembali tradisi yang telah lama berkembang di kalangan masyarakat Banjar. dan ketiga, untuk memfasilitasi mereka yang tidak mampu untuk menyelenggarakan kegiatan ini secara pribadi.

Sebagian besar peserta mengaku mengikutsertakan anaknya dalam kegiatan baayun mulud ini karena berharap mendapatkan keberkahan dari Allah swt terhadap anak-anak mereka; agar anak-anak mereka menjadi anak yang shaleh dan shalehah. Ada juga beberapa di antaranya yang mengikutsertakan anaknya karena sebelumnya pernah bernazar akan mengadakan acara baayun mulud jika anaknya sembuh dari sakitnya. ${ }^{17}$

Memang berbagai tujuan dan kepercayaan dalam baayun mulud tersebut, yakni: karena nazar, melestarikan tradisi, ikut merayakan hari kelahiran Nabi, menciptakan rasa kekeluargaan, ada rasa kuatir bila tidak melaksanakan akan sakit, hal ini karena ada rasa keturunan. ${ }^{18}$ Seorang responden menuturkan keikutsertaannya dalam baayun mulud karena nazar. Sakit yang cukup lama diderita ketika berzanar handak ikut baayun mulud dan bila sembuh akan terus ikut baayun mulud apabila acara itu masih dilaksanakan, dan ternyata

\footnotetext{
${ }^{17}$ Wawancara pribadi dengan Bapak Risfani pada tanggal 12 Juni 2011.

18Wawancara Pribadi dengan Amang Tiak pada 12 Juni 2011.
} 
kebetulan sembuh dari sakit yang sudah lama dirasakan, sehingga pada tahun berikutnya ketika diadakan kembali dan iapun ikut laki ${ }^{19}$.

Ibu Hj. Norlatifah, seorang peserta tertua berusia tidak kurang dari 60 tahun, berasal dari Belitung Darat, Banjarmasin. Mengaku telah mengikuti acara Baayun Mulud untuk kedua kalinya di tempat yang sama. Menurutnya, alasan ikut acara ini adalah karena setahun sebelumnya, ia telah bernadzhar bahwa kalau ia dalam keadaan sehat wal 'afiat selama satu tahun terakhir, maka ia akan ikut lagi kegiatan ini pada tahun ini. ${ }^{20}$

Detalia A mengatakan bahwa Aditia selalu ikut baayun mulud dengan kemauannya sendiri, tanpa ada yang mengajak, baik keluarga ataupun orang lain. Kemauannya untuk ikut baayun mulud ketika akan dilaksanakan, maka apabila tidak disetujui oleh orang tuanya dia akan marah, cengeng, nakal dll. Memang dia diakui oleh keluarganya mempunya hubungan persahabatan mahluk gaib (bagampiran). Orang tuanya selalu menyediakan kopi pahit dan manis setiap malam Jumat. Lain halnya dengan Filyan yang ikut baayun mulud hanya untuk ikut memeriahkan, karena termasuk orang yang berada. ${ }^{21}$

Lain lagi dengan $\mathrm{Hj}$. Mahmudah Herliani, yang mengaku mengikutsertakan anak laki-lakinya yang berumur dua tahun (M. Atha Mudzhar) dalam acara baayun mulud ini dengan harapan agar anaknya kelak menjadi anak yang saleh, cinta kepada Rasulullah Saw., dan mendapat limpahan keberkatan dari Allah swt. ${ }^{22}$

Motivasi lainnya, terungkap dari hasil wawancara dengan penjaga Makam Sultan Suriansyah, Bapak H. Burhan (Jum'at, 22 April 2011) menyatakan bahwa tradisi ini baik dikembangkan di tengah masyarakat muslim sekarang ini, selain berguna untuk lebih mempererat kebersamaan, hubungan persaudaraan, dan persatuan masyarakat, juga untuk memberikan alternatif lain bagi masyarakat muslim dalam memperingati hari kelahiran (ulang tahun) anak-anak mereka. Katanya, "Gasan kakanakan," ("Bagi anak-anak") "Dari pada diperdengarkan nyanyian-nyanyian, lebih baik jika diperdengarkan bacaan sya'ir-sya'ir maulid." 23

Di saat asyraqal ini diyakini bahwa nabi Muhammad hadir dalam majelis itu, dan diharapkan mereka mendapat safaat dari Nabi, serta menjadi orang selalu mendapat keberuntungan dalam hidupnya. Setelah pembacaan syair, semua peserta dipersilakan kembali ke tempat asalnya dengan membawa ayunannya masing-masing. Kemudian setelah

${ }^{19}$ Wawancara Pribadi dengan Aluh pada tanggal 12 Juni 2011.

${ }^{20}$ Wawancara Pribadi dengan $\mathrm{Hj}$. Lathifah pada tanggal 15 Pebruari 2011.

${ }^{21}$ Wawancara pribadi dengan Detali A pada 19 Juni 2011.

${ }^{22}$ Wawancara Pribadi dengan Hj. Mahmudah H pada tanggal 20 Juni 2011.

${ }^{23}$ Wawancara pada hari Jum'at, 22 April 2011 di makam Sultan Suriansyah Kelurahan Kuin Utara Kecamatan Banjarmasin Utara Kota Banjarmasin Provinsi Kalimantan Selatan. 
pembacaan syair dilanjutkan dengan pembacaan doa yang dilanjutkan dengan ceramah agama.

Hampir seluruh peralatan ritual yang disediakan atau digunakan untuk acara Baayun Mulud, dipercayai mengandung beragam makna filosofis. Makna simbolik dari benda-benda yang disediakan tersebut ada yang bersifat umum dan ada pula yang bersifat khusus sesuai dengan harapan yang dicita-citakan peserta yang menyediakannya.

Di antara makna filosofis yang bersifat umum dari benda-benda yang digunakan adalah:

1. Ayunan (buaian) yang terdiri dari kain sarung panjang wanita atau berupa selendang melambangkan peralatan kedaerahan atau budaya lokal yang dipertahankan kelestariannya. Hal ini juga melambangkan kesucian. Seorang wanita harus menjaga kesuciannya termasuk aurat harus ditutupi.

2. Kain kuning sebagai simbol keramat, dengannya diharapkan agar anak yang diayun ini nantinya memperoleh kemuliaan (keramat).

3. Beras kuning melambangkan agar wajah menjadi bagus, indah dan bercahaya.

4. Nasi ketan, melambangkan kecintaan kepada nabi selalu melekat

5. Telor, menggambarkan kebulatan persaudaraan yang kukuh.

6. Tapung tawar untuk menapungtawari peserta.

7. Piduduk (sesajen yang terdiri dari: beras, kelapa, gula merah, garam, dll):

a. Beras merupakan kebutuhan pokok, sebagai simbol kesejahteraan, yakni berkecukupan dalam soal makanan pokok.

b. Kelapa merupakan buah yang serbaguna, sebagai simbol kemanfaatan.

c. Gula merah sebagai melambangkan tutur bahasa manis atau menarik

d. Garam sebagai simbol pengaruh/kewibawaan; (segala ucapannya asin) dengan harapan semoga sang anak menjadi orang yang berpengaruh/berwibawa sehingga kata-katanya diperhatikan orang.

e. Benang menggambarkan tentang urat nadi, diharapkan nantinya selama hidup akan mempunyai ikatan yang kuat dengan keluarga.

f. Jarum melambangkan tulang dalam tubuh. Ini mempunyai harapan yang ikut baayun mulud menjadi orang yang bermanfaat besar bagi orang lain.

g. Uang logam melambangkan bahwa dalam kehidupan ini memerlukan biaya. Karena uang itu memegang peran penting dalam kehidupan ini. Uang logam ini berisi harapan agar mudah rezeki, lancar usaha dan tidak kekurangan.

8. Anyaman-anyaman berupa:

a. Ular-ular melambangkan kehidupan yang penuh dengan liku-liku.

b. Sapit hundang melambangkan adanya kesukaran/kesulitan yang dapat diterima dengan suatu kekuatan.

c. Rantai gagalangan, gambaran kuatnya persaudaraan, rantai ini berjumlah 25 buah, 
sebagai kiasan banyaknya jumlah nabi dan rasul itu 25 orang. ${ }^{24}$

\section{Ragam Motif dan Kepentingan di balik Sebuah Tradisi; Suatu Pembacaan}

Mencermati segala sesuatu yang berhubungan dengan upacara peringatan maulid Nabi di Banjarmasin sebagaimana dikemukakan di atas, tidak bisa dipungkiri bahwa muatan budaya lokal sangat kental memberi warna tersendiri dalam pelaksanaan peringatan maulid tersebut. Peringatan acara yang sama di suatu daerah dapat berbeda cara pelaksanaannya dengan daerah lainnya, namun tidak menghilangkan semangat awal peringatan maulid yaitu menghidupkan kembali semangat keagamaan dengan dibacakannya riwayat kehidupan Nabi Muhammad Saw.

Peringatan maulid nabi di Kalimantan Selatan terutama yang disertai dengan acara maayun anak atau baayun mulud jelas merupakan sebuah tradisi dari hasil akulturasi beragam budaya yang ada di daerah ini. Kepercayaan asli penduduk lokal memberi warna tersendiri dalam peringatan yang bernafaskan Islam. Karena jauh sebelum Islam dibawa ke Kalimantan Selatan, masyarakat Banjar sudah mengenal tradisi maayun anak. ${ }^{25}$ Ketika Islam datang dan bulan maulid diperingati sebagai bulan kelahiran Nabi maka rangkaian peringatan maulid tersebut dimuati dengan acara maayun anak, sehingga tidak bisa dipungkiri akulturasi telah terjadi. Dalam penelitiannya, Wajidi juga menegaskan bahwa tradisi asal baayun mulud dilandasi oleh kepercayaan Kaharingan, hal ini dapat dilihat dari maksud dan tujuan upacara, pelaksanaan, perlengkapan serta lambang dan simbol yang digunakan ketika upacara dilaksanakan. ${ }^{26}$

Bagi Wajidi, upacara maayun anak ini adalah bagian dari rangkaian tradisi bapalas bidan, yaitu upacara pemberkatan yang dilakukan oleh bidan terhadap si bayi dan ibunya agar si bayi terhindar dari bahaya pengaruh magis dari bidan yang telah membantu kelahirannya, karena diyakini bidan beranak memiliki kekuatan magis yang telah membantu dalam proses persalinan, jika bapalas bidan tidak dilaksanakan konon menyebabkan si bayi sakit-sakitan. Bapalas bidan juga dilaksanakan untuk mengakhiri pengaruh kekuatan ghaib si bidan dan sebagai penyerahan bayi kepada orang tuanya karena sebelumnya dianggap sebagai anak si bidan. ${ }^{27}$ Selain juga sebagai balas jasa kepada bidan karena upacara ini disertai dengan pemberian beberapa hadiah kepada bidan.

Bapalas bidan biasanya dilaksanakan ketika bayi berusia 40 (empat puluh) hari, si anak dibuatkan ayunan yang diberi hiasan menarik seperti udang-udangan, belalang, urung

\footnotetext{
${ }^{24}$ Wawancara Pribadi dengan Bardi, M. Akli dan Munia pada Tanggal 20 Juni 2011

25Wajidi, Akulturasi Budaya Banjar di Banua Halat (Yogyakarta: Pustaka Book Publisher, 2011), 106.

26Wajidi, Akulturasi Budaya Banjar di Banua Halat, 107

${ }^{27}$ Wajidi, Akulturasi Budaya Banjar di Banua Halat, 108
} 
ketupat berbagai bentuk serta digantungkan bermacam kue seperti kue cucur, cincin, apam, pisang dan lain-lain. Kepada bidan yang telah berjasa menolong persalinan diberikan hadiah segantang beras, jarum, benang, seekor ayam (ayam jantan jika laki-laki dan ayam betina jika perempuan) sebiji kelapa, rempah-rempah dan bahan untuk menginang seperti sirih, kapur, pinang, gambir, tembakau dan berupa uang. ${ }^{28}$

Masyarakat Banjar sudah lama menganut agama Islam, dan dipandang sebagai masyarakat yang agamis, namun dalam kenyataan masih ditemukan unsur-unsur yang tidak dapat begitu saja dianggap sebagai bersumber dari ajaran Islam. Dalam berbagai peristiwa kehidupan sehari-hari, banyak kebiasaan dan tradisi-tradisi yang bercampur dengan ajaran agama Islam. Percampuran antara agama dengan tradisi itu ternyata tidak mudah dihindari.

Pischer menyebutkan adanya "osmose"(percampuran) antara religi kerakyatan dengan religi yang didatangkan. Religi kerakyatan adalah keberagamaan yang tumbuh secara natural dalam kehidupan rakyat. Keberagamaan ini melekat bersama ajaran agama dalam kehidupan masyarakat yang kemudian menganut agama itu, sehingga terjadi sinkretisme. Sinkretisme ini terjadi karena beberapa faktor: (a) adanya pengakuan secara tidak nyata kepada adanya otoritas yang menentukan suasana kehidupan kini dan akan datang. (b) Pengakuan itu mendasari cara kerja yang tidak memerlukan pengetahuan, hukum, sebab akibat yang lazim dalam dunia empiris. (c) Legitimasi cara kerja dan perbuatan yang sebenarnya bertentangan dengan Islam. ${ }^{29}$

Dari sekian banyak tradisi yang masih dipertahankan oleh masyarakat kita adalah kepercayaan upacara baayun mulud. Penyelenggaraan baayun mulud di kota Banjarmasin telah menjadi event tahunan yang semakin marak dan terus mengalami perkembangan. Tradisi budaya religius yang melibatkan umat Islam, baik sebagai peserta maupun panitia penyelenggara dan mendapat dukungan penuh dari aparatur pemerintah ini hampir dipastikan akan tetap eksis di tengah masyarakat Banjar. Jalinan beragam motivasi dan kepentingan di balik pelaksanaan tradisi khas masyarakat Banjar ini turut melanggengkan eksistensinya di tengah gempuran budaya global.

Jika dilihat perkembangannya sampai sekarang, ada beberapa kitab maulid yang sering digunakan, seperti: maulid Syarf al-Anâm yang disusun oleh 'Allâh asy-Syarf, maulid alBarzanjî yang disusun oleh Ja'far ibn Muhammad al-Barzanjî, maulid ad-Dibâ'î yang disusun oleh 'ar-Rahmân ad-Dibâ'î, maulid al' $A \not z b$ yang disusun oleh Muhammad Abu 'Allâh al'Azb, dan maulid al-Habsyî (Simth ad-Durar) yang disusun oleh 'Alî ibn Muhammad ibn alHusayn al-Habsyî. Dapat dilihat dengan jelas bahwa kitab-kitab maulid tersebut disusun oleh Dzuriat atau keturunan dari Nabi Muhammad Saw. yang dikenal dengan nama habib atau al-sayyed. Syair-syair yang termaktub dalam kitab-kitab tersebut berisi tentang perangai

${ }^{28}$ Wajidi, dikutip dalam Ideham, 2007:76

${ }^{29}$ Noordiansyah, Sinkritisme, (Fakultas Ushuluddin IAIN Antasari Banjarmasin, 1982), 19-20 
Rasulullah Saw. dan perjalanan kehidupan beliau sejak lahir sampai meninggal. Seiring dengan perkembangannya, kitab al-Habsyi inilah yang populer dibaca.

Di Kalimantan Selatan, khususnya di Banjarmasin, kitab-kitab tersebut telah sejak lama beredar dan sering dibaca ketika peringatan maulid Nabi Saw. berlangsung. Kitab yang disebut terakhir inilah (Simth ad-Durar) yang dikenal dengan maulid al-Habsyî dan paling masyhur di kalangan masyarakat Banjar sekarang, karena ia pernah dipopulerkan oleh seorang ulama kharismatik Banjar, yaitu K.H. Muhammad Zaini bin Abdul Ghani (1948 2005 M.) dan bahkan mampu menggeser kitab-kitab maulid lainnya seperti Syarf al-Anâm, al-Barzanjî dan ad-Dibâ î yang pernah populer pada tempo dulu. ${ }^{30}$

Di saat syair-syair maulid dilantunkan dengan indahnya, peserta baayun mulud mulai menempati ayunan baik anak-anak atau orang dewasa. Ketika asyraqal seluruh peserta diayun oleh orang tuanya ataupun keluarganya. Menurut kepercayaan masyarakat Banjar bahwa ketika dibacakan asyraqal itulah Rasulullah Saw. hadir di tengah-tengah majelis maulid. Di samping kepercayaan hadirnya Rasulullah Saw. mereka (para peserta) juga berharap akan mendapatkan syafaat dari nabi, serta menjadi orang yang selalu mendapat keberuntungan dalam hidupnya. Biasanya pada saat kalimat itu dibacakan, semua jamaah langsung berdiri sebagai simbol penghormatan atas kehadiran ruh Nabi Muhammad Saw.

Masalah berdiri ketika dibacakan tentang sejarah perjalanan kehidupan Rasulullah Saw. adalah suatu bentuk kehormatan dan kemuliaan seorang Nabi Muhammad sebagai utusan Allah. Hal ini sebagaimana yang diungkapkan oleh al-Shafuri al-Syafi'i memberikan komentar berdiri pada saat pembacaan sejarah - pada saat kelahiran - nabi, tidak ada larangan. Menurutnya lagi perbuatan ini merupakan bid'ah yang baik. Bahkan ada sekelompok orang yang menyatakan secara ekstrem justru menyatakan sunnah. Penghormatan yang demikian semata-mata sebagai bentuk penghormatan dan pengagungan Nabi Muhammad Saw. dan hukum menghormati merupakan suatu keharusan bagi seorang mukmin. Dengan demikian tujuan dari berdiri dimaksud dalam kepercayaan adalah sebagai bentuk penghormatan dan memuliakan sebagai seorang rasul yang telah membimbing manusia dari kesesatan kepada hidayah dan cahaya iman, Islam. ${ }^{31}$

Dalam tradisi acara maulid terdapat kepercayaan bahwa ketika asyraqal, seluruh peserta berdiri, meyakini bahwa ruh Rasulullah Saw. hadir di majelis tempat dibacakan syairsyair tentang pujian kepada Nabi Muhammad. Berkaitan dengan hadirnya roh Nabi Muhammad ketika dibacakan syair-syair maulid menarik untuk disimak penjelasan yang dikemukakan oleh Ibnu Qayyim dalam karyanya al-Rub dalam subbahasan tentang roh yang

${ }^{30}$ Ahd. Zamani, et al. Pemahaman Hadis-hadis Nur Muhammad Menurut Ulama Kota Banjarmasin (Banjarmasin: Antasari Press, 2008), 4.

${ }^{31}$ Ja'far Murtadha al-'Amanily, Perayaan Maulid, Khaul dan Hari-hari Besar Islam Bukan Sesuatu yang Haram, terj. Masykur Ab (Bandung: Pustaka Hidayah, 1996), cet. ke-3, 24. 
orang mati dapat bertemu dengan ruh orang yang masih hidup dengan mengemukan Q.S. al-Zumar ayat 42 :

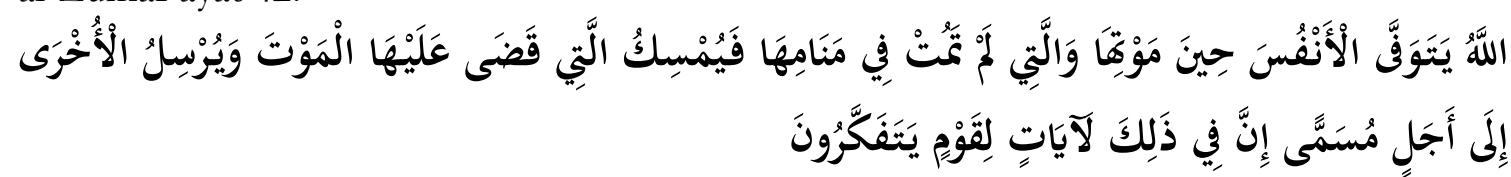

"Allah memegang jiwa (orang) ketika matinya dan (memegang) jiwa (orang) yang belum mati di waktu tidurnya; Maka dia tahanlah jiwna (orang) yang telah dia tetapkan kematiannya dan dia melepaskan jiwa yang lain sampai waktu yang ditetapkan. Sesunggubnya pada yang demikian itu terdapat tanda- tanda kekuasaan Allah bagi kaum yang berpikir."

Ibnu Qayyim menyebutkan riwayat dari Ibnu Abbas tentang ayat ini, dia,"Telah sampai kepadaku bahwa roh orang-orang yang masih hidup dan roh orang-orang yang sudah mati bisa bertemu di dalam mimpi. Mereka saling bertanya lalu Allah swt. menahan roh orang-orang yang sudah mati dan melepaskan roh orang-orang yang masih hidup menemui jasadnya. Selain itu, Ibnu Abi Hatim di dalam tafsirnya menyebutkan riwayat dari al-Suddiy tentang makna firman Allah swt. "Dan jiwa yang belum mati di waktu tidurnya" adalah mematikannya saat tidurnya lalu roh orang yang masih hidup bertemu dengan roh orang yang sudah mati dan mereka saling berbincang, berkenalan. Dia mengatakan, "lalu roh orang yang masih hidup dikembalikan kepada jasadnya di dunia hingga sisa waktu yang telah ditentukan sementara itu roh orang yang sudah mati menginginkan kembali ke jasadnya namun dia tertahan."

Dalam upacara baayun mulud ini setelah pembacaan syair-syair maulid, dilanjutkan dengan ceramah agama, ceramah agama ini disampaikan oleh seorang ulama yang telah diminta untuk menyampaikan tentang sejarah perjalanan dan perjuangan Nabi Muhammad (sirah nabawiyyah). Tujuan dari ceramah ini untuk menumbuhkan kecintaan kepada Nabi Muhammad Saw. dan meneladani sifat dan akhlak beliau.

Jika ingin dicermati, penerapan upacara adat baayun Anak merupakan akulturasi kebudayaan dengan dakwah ajaran Islam. Penghormatan yang sebelumnya dipersembahkan kepada leluhur, diselaraskan dengan ajaran Islam, yakni agar si anak dapat mendapat sifatsifat baik seperti yang dimiliki oleh Nabi Muhammad. Akulturasi terhadap tradisi ini terjadi secara damai dan harmonis serta menjadi substansi yang berbeda dengan sebelumnya karena tradisi lama berubah menjadi tradisi baru yang bernafaskan Islam.

Dengan demikian Baaynn Mulud merupakan sebuah tradisi yang dapat dimaknai sebagai suatu upaya untuk menyampaikan ajaran Islam dengan mengakomodir budaya lokal serta lebih menyatu dengan lingkungan hidup masyarakat setempat. Dakwah kultural memang menghendaki adanya kecerdikan dalam memahami kondisi masyarakat dan kemudian mengemasnya sesuai dengan pesan-pesan yang terkandung dalam dakwah Islam. Dengan demikian, upacara adat Baayun Mulud atau Baayun Anak sudah menjadi salah satu simbol pertemuan antara tradisi dan ajaran agama. Mengayun anak, jelas sebuah tradisi lokal 
yang dilakukan oleh masyarakat Banjar dan Dayak secara turun-temurun dari dulu hingga sekarang untuk menidurkan anak-anak. Sedangkan memberi nama anak, berdoa, membaca shalawat, membaca Alquran, dan silaturahmi merupakan anjuran dan perintah agama Islam. Kedua ritus ini secara harmoni telah bersatu dalam kegiatan Baayun, yang bahkan secara khusus dilaksanakan sebagai peringatan sekaligus penghormatan atas kelahiran Nabi Muhammad Saw. yang kemudian dikenal dengan Baayun Mulud. ${ }^{32}$

Akhirnya upacara tersebut bisa "diislamisasikan". Sehingga jika sebelumnya upacara ini diisi dengan bacaan-bacaan balian, mantra-mantra, doa dan persembahan kepada para dewa dan leluhur, nenek moyang di Balai, akhirnya digantikan dengan pembacaan syair-syair maulud, yang berisi sejarah, perjuangan, dan pujian terhadap Nabi Muhammad Saw., dilaksanakan di masjid, sedangkan sistem dan pola pelaksanaan upacara tetap. ${ }^{33}$

Di samping itu Baayun anak adalah proses budaya yang menjadi salah satu simbol kearifan dakwah ulama Banjar dalam mendialogkan makna hakiki ajaran agama dengan budaya masyarakat Banjar. Maulid adalah simbol agama dan menjadi salah satu manifestasi untuk menanamkan, memupuk, dan menambah kecintaan sekaligus pembumian sosok manusia pilihan, manusia teladan, Nabi pembawa Islam, untuk mengikuti ajaran dan petuahnya. Sedangkan baayun anak penerjemahan dari manifestasi tersebut, karena dalam baayun anak terangkum deskripsi biografi Nabi Saw. sekaligus doa, upaya, dan harapan untuk meneladaninya. ${ }^{34}$

Baayun anak juga wujud nyata geneus lokal dalam menerjemahkan hadis dan perintah Nabi untuk menuntut ilmu sejak dari buaian (ayunan). "Tuntutlah ilmu dari sejak dalam buaian (ayunan) hingga liang lahat". Ilmu yang dituntut adalah ilmu yang telah dianjurkan oleh Nabi; mencakup ilmu dunia dan ilmu akhirat. "Barangsiapa yang ingin memperoleh kebaikan (kebahagiaan) di dunia, maka tuntutlah ilmu; dan barangsiapa yang ingin mendapatkan kebaikan di akhirat, maka tuntutlah ilmu; dan barangsiapa yang ingin memperoleh kebaikan di kedua-duanya, maka tuntutlah ilmu” (HR. Imam Muslim).

Oleh karenanya, ketika terjadi ketegangan dan pertikaian, disebabkan oleh seni, tradisi, budaya lokal atau adat-istiadat yang tidak sejalan dengan agama, diperlukan rekonsialisasi melalui sentuhan dakwah, yang sekarang dikenal sebagai pendekatan dakwah kultural. Dakwah kultural adalah dakwah bijak untuk mempertemukan (mengislamisasikan) tradisi budaya agar tidak bertentangan dengan ajaran agama. Jadi, dakwah kultural tidak hanya sebatas menggunakan medium seni budaya. Atau sebagai suatu upaya menyampaikan ajaran Islam dengan mengakomodir budaya lokal serta lebih menyatu dengan lingkungan hidup masyarakat setempat. Namun, dakwah kultural menghendaki adanya kecerdikan

32Dikutip dari http://zuljamalie.blogdetik.com). Diakses pada tanggal 20 September 2011

${ }^{33}$ Dikutip dari http://zuljamalie.blogdetik.com). Diakses pada tanggal 20 September 2011

${ }^{34}$ Dikutip dari http://zuljamalie.blogdetik.com). Diakses pada tanggal 20 September 2011 
dalam memahami kondisi masyarakat dan kemudian mengemasnya sesuai dengan pesanpesan dakwah Islam. Sehingga, dengan begitu, sebuah tradisi tetap akan terjaga dan lestari, dan tentu saja tidak bertentangan dengan ajaran agama, sebagaimana halnya dengan tradisi baayun anak. ${ }^{35}$

Baayun anak adalah salah satu simbol pertemuan antara tradisi dan ajaran agama. Mengayun anak, jelas sebuah tradisi lokal yang dilakukan oleh masyarakat Banjar dan Dayak secara turun-temurun dari dulu hingga sekarang untuk menidurkan anak-anak. Sedangkan memberi nama anak, berdoa, membaca salawat, ataupun membaca Alquran, dan silaturahmi merupakan anjuran dan perintah agama. Kedua ritus, secara harmoni telah bersatu dalam kegiatan baayun anak, yang bahkan secara khusus dilaksanakan pada bulan Rabiul Awal (bulan Maulid) sebagai peringatan sekaligus penghormatan atas kelahiran Nabi Muhammad Saw. ${ }^{36}$

Dengan demikian pelaksanaan upacara Baayun Mulud atau Baayun Anak, yang kemudian berpadu dengan kebudayaan Islam, mengandung nilai-nilai sebagai berikut:

1. Meneladani dan mengambil berkah atas keluhuran dan kemuliaan yang dimiliki oleh Nabi Muhammad Saw.

2. Wujud nyata kearifan lokal dalam menerjemahkan badis dan perintah Nabi untuk menuntut ilmu sejak dari buaian (ayunan). Ilmu yang dituntut adalah ilmu yang telah dianjurkan oleh Nabi, yakni mencakup ilmu dunia dan ilmu akhirat.

3. Dalam pelaksanaan upacara ini terkandung harapan agar si anak yang diayun selalu mendapat kebaikan dalam menempuh kehidupan yang selanjutnya.

4. Sebagai bentuk pelestarian tradisi leluhur namun dengan tetap menjaga nilai-nilai keislaman.

5. Sebagai salah satu upaya untuk mewariskan dan mengenalkan tradisi urang Banjar kepada generasi muda penerus bangsa.

Selain itu, doa-doa dan berbagai perlengkapan yang digunakan dalam upacara adat Baayun Mulud/Baayun Anak juga memuat nilai-nilai tertentu. Misalnya, susunan bahan-bahan dalam piduduk, antara lain beras dimaksudkan agar paras muka si anak menjadi lebih rupawan, kelapa dan gula memuat maksud supaya tutur kata si anak menjadi halus dan senantiasa berkata-kata manis (baik), garam dengan harapan agar pembawaan si anak menjadi berwibawa, dan minyak goreng (bagi anak perempuan) ditujukan supaya si anak menjadi orang yang peka terhadap sekitarnya. ${ }^{37}$

${ }^{35}$ Dikutip dari http://zuljamalie.blogdetik.com). Diakses pada tanggal 20 September 2011

${ }^{36}$ http://zuljamalie.blogdetik.com). Diakses pada tanggal 20 September 2011

${ }^{37}$ http://baayun-mulud-upacara-adat-suku-banjar-kalimantan-selatan. htm. Diakses pada tanggal 23 September 2011 
Islam yang ideal dan benar sebagaimana dicontohkan atau yang diajarkan oleh Nabi Muhammad, hal inilah disebut Islam Normatif. Sedangkan Islam seperti yang senyatanya terjadi dalam masyarakat disebut Islam Historis, Islam Kontekstual atau juga bisa disebut Islam Empiris. Yakni Islam dalam kenyataan, yang dapat diamati, benar-benar terjadi, benar-benar diamalkan oleh manusia atau masyarakat, terkait atau yang disesuaikan dengan konteks ruang dan waktu, kapan dan di mana Islam diamalkan oleh manusia atau masyarakat tersebut. ${ }^{38}$

Islam yang ada di Kalimantan Selatan sebagaimana yang dipraktekkan oleh masyarakat suku Banjar merupakan Islam yang telah dipengaruhi oleh historisitas wilayah ini. Sekalipun masyakarat Banjar dapat dinilai sudah cukup maju dari aspek pendidikan, ekonomi, dan pengetahuan keberagamaan, namun budaya atau adat-istiadat yang sudah melekat dalam kehidupan masyarakat Banjar jauh sebelum kedatangan Islam di daerah ini tetap saja terasa kental mewarnai corak keberagamaan mereka saat ini. Hal ini sangat dirasakan dalam pelaksanaan tradisi baayun mulud ini.

Bagi orang Islam, secara umum peringatan maulid nabi biasanya dimaksudkan untuk mengenang kembali peristiwa bersejarah lahirnya Nabi Muhammad Saw., seorang tokoh besar pembawa risalah ilahi yang segala sisi dari hidup dan kehidupannya mengandung 'ibrah dan merupakan teladan dalam mencapai kebahagiaan hidup di dunia dan di akhirat. Bagi seorang muslim, memperingati maulid Nabi Muhammad Saw. merupakan sebuah ekspresi keberagamaan, mulai dari rasa syukur atas kehadiran seseorang yang sangat berjasa; pembawa cahaya petunjuk dari "alam kegelapan ke alam yang terang-benderang." Hingga rasa cinta kepada sosok sang pembawa risalah yang memiliki akhlak dan budi pekerti utama.

Sekalipun tidak ditemukan contoh tentang peringatan maulid dari Sang Nabi sendiri, demikian pula dari para sahabatnya, sebagian besar umat Islam yang menyelenggarakan peringatan maulid Nabi Muhammad Saw. Meyakini atau mempercayai bahwa apa yang mereka lakukan bukanlah sesuatu yang terlarang dalam Islam, namun justeru sebaliknya, merupakan sesuatu yang bernilai ibadah kepada Allah swt., karena bagi mereka tujuan peringatan tersebut adalah diniatkan agar umat Islam mengenal lebih dekat sosok dan kepribadian sang Nabi sehingga dapat lebih mencintainya dan kemudian meneladani jejak langkahnya dalam hidup dan kehidupan.

Adapun maksud diadakan acara baayun mulud dalam rangkaian peringatan maulid Nabi Muhammad Saw., di samping untuk memeriahkan acara peringatan maulid itu sendiri, dimaksudkan pula sebagai sarana untuk menanamkan nilai-nilai religiusitas bagi anak-anak

${ }^{38}$ Khadziq, Islam dan Budaya Lokal (Yogyakarta: Teras, 2009), Cet. ke-1, 10-11. 
sedini mungkin. ${ }^{39}$ Mereka yang mengikutsertakan anak-anaknya dalam acara baayun mulud, pada umumnya berharap semoga anak-anak mereka kelak memiliki budi pekerti yang mulia dan meneladani jejak langkah Rasulullah Saw.. Melalui acara pembacaan sya'ir-sya'ir pujian dan shalawat atas Rasulullah yang mengiringi acara baayun, para pesertanya juga berharap mendapat keberkahan dari Allah swt, berupa keselamatan, kesehatan, dan kemurahan rezki selama setahun ke depan. Mereka sangat meyakini keberkahan bershalawat kepada Rasulullah Saw., yang memang dinyatakan dalam sebuah hadis, yang diriwayatkan oleh Imam Muslim sebagai berikut:

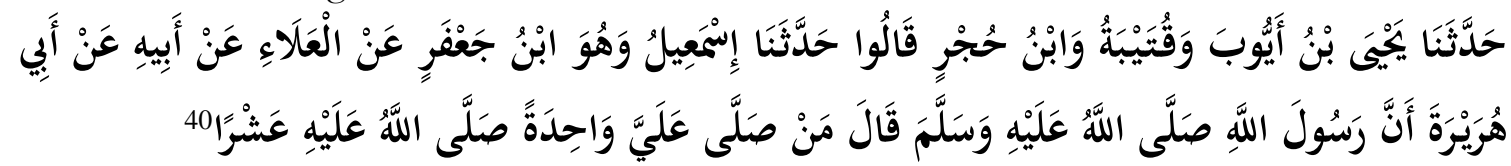

Imam Muslim menyatakan, telah berbicara kepada kami Yabya bin Ayyun, Qutaibah, dan Ibn Hujr, mereka berkata, telah berbicara kepada kami Isma'il, yaitu Ibn Ja'far dari al-'Ala dari Ayahnya dari Abi Hurairah bahwa Rasulullah saw bersabda "Siapa yang bershalawat kepadaku sekali, Allah akan bershalawat untuknya sepulub kali."

Penyelenggaraan baayun mulud di kota Banjarmasin telah menjadi event tahunan yang semakin marak dan terus mengalami perkembangan. Tradisi budaya religius yang melibatkan umat Islam, baik sebagai peserta maupun panitia penyelenggara dan mendapat dukungan penuh dari aparatur pemerintah ini hampir dipastikan akan tetap eksis di tengah masyarakat Banjar. Jalinan beragam motivasi dan kepentingan di balik pelaksanaan tradisi khas masyarakat Banjar ini turut melanggengkan eksistensinya di tengah gempuran budaya global.

Adanya beragam tujuan dan kepentingan di balik pelaksanaan tradisi baayun mulud di kota Banjarmasin terungkap dari keterangan mereka yang terlibat secara langsung maupun tidak langsung dengan kegiatan tersebut. Beragam motif dan kepentingan yang mendorong langgengnya tradisi ini di tengah masyarakat Banjar dapat dirincikan sebagai berikut:

1. Motivasi Religius

Baik religiusitas yang bernafaskan Islam maupun religiusitas yang bersumber dari agama-agama lainnya atau kepercayaan-kepercayaan lokal yang telah lama dikenal di tengah masyarakat Banjar. Dimensi religiusitas dalam upacara baayun mulud, jelas sekali tampak bagi siapa pun yang hadir menyaksikannya. Bagi mereka yang memandang dari

اطلبوا العلم من المهد الى اللحد (tuntutlah ilmu dari buaian hingga ke liang lahat), dapat dilihat dalam Haqqî, Tafsîr Haqqî, www.al-tafsir.com

${ }^{40}$ Shahîh Muslim, Kitâb al-Shalâh, Bâb al-Shalâh 'ala al-Nabî ba'da al-Tasyahbud, hadis nomor 616: lihat juga dalam Sunan al-Turmudrî, Kitab al-Shalâh hadis nomor 447; Sunan al-Nasầ Kitâb al-Sabwu hadis nomor 1279; Sunan Abi Daud, Kitab al-Shalâh hadis nomor 1307. 
sisi historisitas Islam dan yang meyakini karakter kosmopolitan Islam sebagai agama, mungkin akan menilai bahwa nafas Islam telah berhasil menjadi ruh bagi sebuah tradisi budaya lokal yang telah lama dikenal oleh masyarakat Banjar. Akan tetapi, bagi mereka yang lebih menekankan sisi normativitas Islam sebagai ajaran Ilahi, mungkin akan menilai bahwa tradisi tersebut merupakan sebuah sinkritisme yang seharusnya dimurnikan dari ajaran Islam.

Tidak ada yang mengingkari bahwa Islam bukanlah agama atau kepercayaan pertama yang dikenal oleh penduduk asli yang menghuni wilayah nusantara. Islam sebagaimana juga Hindu, Budha, dan Kristen merupakan agama-agama atau kepercayaan baru bagi penduduk asli di wilayah nusantara. Agama atau kepercayaan asli Indonesia, menurut ahli agama-agama primitif, Prof. Rachmat Subagya, merupakan konsep-konsep keruhanian dalam masyarakat suku yang secara internal tumbuh, berkembang dan mencapai kesempurnaannya sendiri tanpa imitasi atau pengaruh eksternal. ${ }^{41}$

Secara kronologis dapat disebutkan bahwa agama Hindu dan Budha merupakan dua agama yang pertama kali berinteraksi dengan kepercayaan asli Indonesia. Sementara agama Islam merupakan agama ketiga yang mencapai batas-batas wilayah nusantara setelah sebelumnya wilayah ini dirasuki secara mendalam oleh agama Hindu dan Budha. Agama Hindu dan Budha mengalami perkembangan pesat di wilayah nusantara sejak abad pertama dan kedua Hijriah. Di Sumatera dan Jawa berdiri kerajaan-kerajaan yang memiliki keterkaitan dengan kedua agama tersebut. Peninggalan besar kedua agama tersebut berupa candi Prambanan dan candi Borobudur merupakan saksi sejarah yang paling otentik suksesnya perkembangan kedua agama tersebut di wilayah nusantara.

Adapun di wilayah Kalimantan Selatan, berdasarkan hikayat yang dihimpun J.J. Ras, seperti dikutip Mujiburrahman, dinyatakan bahwa kerajaan pertama yang muncul di daerah ini adalah kerajaan Tanjungpura yang berpusat di Tanjung dan didirikan oleh para imigran Melayu Sriwijaya yang beragama Budha. Kemudian pada abad XIII, kaum imigran dari Jawa mendirikan kerajaan Negara Dipa di Amuntai dan menganut agama Hindu. Oleh karenanya dapat disimpulkan bahwa sebelum Islam menjadi agama resmi kerajaan Banjar, masyarakat di wilayah ini, sebagaimana halnya masyarakat di wilayah lainnya di nusantara, telah mengenal Budhisme dan Hinduisme selain kepercayaankepercayaan primitif seperti animisme, dinamisme dan shamanisme. ${ }^{42}$

\footnotetext{
${ }^{41}$ Rachmat Subagya, Kepercayaan Kebatinan, Kerohanian, dan Agama (Jakarta: Yayasan Kanisius, 1970),
} 31. 2008), 389 .

\footnotetext{
${ }^{42}$ Mujiburrahman, Mengindonesiakan Islam: Representasi dan Ideologi (Yogyakarta: Pustaka Pelajar,
} 
Perkembangan Islam di tengah masyarakat Banjar tidak terlepas dari perkembangan Islam di wilayah nusantara secara umum. Islamisasi di wilayah nusantara lebih kurang terjadi antara abad XIII hingga abad XV masehi. Proses Islamisasi ini terjadi secara perlahan, berangsur-angsur hingga Islam berintegrasi dengan berbagai budaya yang ada di nusantara. ${ }^{43}$ Proses penyebaran dan pemelukan agama Islam di kepulauan nusantara yang berlangsung secara massif dan dengan jalan damai tersebut sempat dicatat oleh Marshall Hodgson sebagai prestasi sejarah dan budaya yang amat sangat mengagumkan. ${ }^{44}$ Di sisi lain, konversi ke dalam agama Islam yang berlangsung secara damai tersebut tentunya dibarengi dengan tingkat akomodasi yang tinggi dari agama Islam sebagai pendatang baru terhadap institusi-institusi agama dan kepercayaan yang sudah ada.

Pengaruh agama-agama sebelumnya atau kepercayaan asli Indonesia terhadap agama-agama pendatang, tidak terkecuali agama Islam merupakan realitas yang tidak dapat dimungkiri. ${ }^{45}$ Bahkan menurut Seno Harbangan Siagian, setiap orang Indonesia bagaimanapun majunya, tetap terpengaruh oleh agama asli yang sedikit banyaknya melekat pada keyakinan barunya, baik dia seorang pengikut Hindu, Budha, Islam, maupun Kristen. ${ }^{46}$

Realitas keberagamaan tersebut di atas juga terjadi di tengah-tengah masyarakat muslim yang tinggal di kota Banjarmasin hingga saat ini. Kasus berupa upacaya baayun mulud merupakan salah satu bentuk realitas keberagamaan dimaksud. Upacara yang merepresentasikan sebuah tradisi budaya khas masyarakat Banjar ini tidak saja diliputi oleh unsur-unsur Islam, tetapi juga diwarnai oleh tradisi agama atau kepercayaan selain Islam.

Unsur-unsur Islam yang tampak jelas dari upacara tersebut, di antaranya adalah: Pertama, bahwa upacara tersebut digelar seiring dengan peringatan kelahiran pembawa risalah Islam, yaitu Nabi Muhammad Saw. Kedua, upacara baayun mulud ini diikuti seluruhnya oleh orang yang mengaku muslim, baik peserta yang diayun, keluarga dan kerabatnya yang hadir maupun panitia yang mengadakan acara. Ketiga, bacaan-bacaan baik berupa ayat-ayat al-Qur ân, do'a-do'a yang dipanjatkan, maupun sya'ir-sya'ir yang dilantunkan keseluruhannya merupakan representasi dari unsur-unsur Islam. Keempat,

${ }^{43}$ Mujiburrahman, Mengindonesiakan Islam: Representasi dan Ideologi, 387.

${ }^{44}$ Baca dalam M. Amin Abdullah, Studi Agama: Normativitas atau Historisitas? (Yogyakarta: Pustaka Pelajar, 1996), 5 \& 19. Menurut Amin Abdullah, Hodgson sengaja menonjolkan aspek ini sebagai jawaban atas tesis Cliiford Geertz yang kurang apresiatif terhadap hasil budaya yang sangat mengagumkan tersebut.

${ }^{45}$ Alwi Shihab, Antara Tasawnf Sunni dan Tasawuf Falsafi: Akar Tasawuf di Indonesia (Jakarta: Pustaka Iiman, 2009), 1.

46Seno Harbangan Siagian, Agama-Agama di Indonesia (Semarang: Setia Wacana, 1987), 1-5. 
tempat penyelenggaraan acara baayun mulud ini, baik di mesjid maupun di komplek pemakaman sultan (gelar untuk penguasa di Kerajaan Banjar yang beragama Islam), keduanya merupakan simbol-simbol Islam. Kelima, salah satu rangkaian acara dalam kegiatan baayun mulud ini adalah ceramah agama yang diisi oleh seorang ulama yang tentunya merupakan representasi dari pemuka agama Islam.

Adapun unsur-unsur asing dari luar Islam yang segera tampak dari acara baayun mulud ini adalah pertama, dari peralatan yang disiapkan dan dipergunakan, yaitu seperti Adanya semacam sesajen yang oleh masyarakat Banjar disebut dengan istilah piduduk dan anyaman-anyaman beragam bentuk terbuat dari daun nipah atau daun kelapa sebagai pernak-pernik penghias ayunan. Kedua, pada saat prosesi acara baayun mulud berlangsung, seorang ulama yang memimpin do'a berkeliling ke seluruh peserta yang diayun sambil memercikkan air kembang yang telah dido'akan (sehingga dipercaya mengandung berkah) ke arah peserta. Prosesi seperti ini oleh masyarakat Banjar disebut dengan istilah batutungkal.

Jika ditinjau secara normatif, upacara baayun mulud yang dalam pelaksanaannya melibatkan unsur-unsur Islam dan non-Islam tersebut akan memunculkan pertanyaan seperti: Apakah pengaruh-pengaruh kepercayaan atau agama-agama sebelumnya dalam upacara tersebut merupakan sesuatu yang masih dapat ditoleransi oleh Islam ataukah sebuah sinkritisme yang seharusnya dihapuskan atas nama kemurnian agama Islam?

Sebelum dikemukakan analisis pandangan Islam secara normatif terhadap kasus tersebut, perlu ditegaskan sebelumnya bahwa pelaksanaan acara peringatan maulid Nabi Muhammad Saw. sendiri tidaklah disepakati kebolehannya oleh seluruh ulama dari kalangan umat Islam.

Kelompok yang belakangan mengklaim dirinya sebagai kaum salafi misalnya, dengan tegas menolak acara-acara semacam itu. Menurut mereka, acara seperti itu termasuk kategori bid'ah, karena jangankan diperintahkan, dikerjakan pun tidak pernah oleh Rasulullah Saw. Demikian pula oleh para sahabatnya, hingga tiga generasi pertama umat Islam, mereka tidak pernah melakukannya. ${ }^{47}$ Senada dengan pandangan kelompok ini, kelompok-kelompok Islam di Indonesia yang biasanya dikategorikan sebagai

\footnotetext{
${ }^{47}$ Baca fatwa Shâlih bin Fauzân bin 'Abdillah al-Fauzân, Kitâb al-Taunhîd, (al-Mamlakah al-'Arabiyyah al-Sa'udiyyah: Wizârah al-Syu'ûn al-Islâmiyyah wa al-Awqâf wa al-Da'wah wa al-Irsyâd, 1423 H), juz I, hal. 155; 'Abd al-'Azîz bin 'Abdullah bin Bâz, Fatâwâ al-Mar'ah al-Muslimah, (Kairo: Dâr Ibn al-Jauzî, 2005), hal. 556; Baca juga kitab al-Mausu'ah al-Radd 'alâ al-Shûfiyyah dan kitab al-Jâmi' fi al-Maulid yang merupakan Majmû́ah Maqâlât wa Fatâwâ 'an al-Intifâl bi al-Maulid al-Nabawr̂, dalam al-Maktabah al-Syâmilah, al-Ishdâr 3,5 atau diunduh di http:/ /www.shamela.ws
} 
kelompok modernis, seperti Persis dan Muhammadiyah juga mengecam pelaksanaan acara peringatan maulid nabi karena menganggapnya sebagai $b i d^{\prime} a b^{48}$.

Jika forum yang mengagendakan acara peringatan maulid Nabi Muhammad Saw. saja dikecam sebagai bid'ah yang terlarang oleh kelompok-kelompok tersebut di atas, maka apatah lagi acara tradisi budaya baayun mulud yang seperti telah diungkapkan banyak mengandung unsur-unsur sinkritisme antara Islam dan non-Islam.

Memang diakui bahwa dalam pelaksanaan tradisi baayun mulud di kota Banjarmasin masih terdapat beberapa fenomena yang dapat dianggap sebagai sisa-sisa ritus pra-Islam. Akan tetapi, sudah tidak terdeteksi lagi kepercayaan atau aqidah yang benar-benar dapat dinilai menyimpang dari ajaran Islam. Contoh konkritnya adalah sesajen atau yang disebut dengan piduduk yang disediakan di sekitar ayunan oleh keluarga yang diayun. Jika dahulunya sesajen atau piduduk tersebut dimaksudkan sebagai persembahan bagi makhluk gaib atau roh-roh halus yang dapat mengganggu, sekarang ini, keberadaan piduduk tersebut hanyalah dianggap sebagai pernak-pernik budaya yang melengkapi gelaran sebuah tradisi. Asumsi pertama bahwa piduduk tersebut disediakan karena adanya kepercayaan terhadap pengaruh roh-roh halus atau makhluk-makhluk gaib tampaknya tidak dapat dipertahankan karena ternyata sesajen berupa makanan, telor, dan kue-kue yang dihamparkan tersebut, akhirnya justru jadi bahan rebutan anggota keluarga peserta untuk dinikmati bersama-sama sehingga tidak ada lagi sisa sesajen yang awalnya diduga akan diberikan kepada makhluk gaib.

Kepercayaan terhadap adanya makhluk gaib atau roh-roh halus yang dapat berpengaruh terhadap kehidupan manusia sebenarnya telah lama dikenal oleh masyarakat di daerah ini. Sejak abad ke-18 M, kepercayaan tersebut telah dikecam keras oleh Syekh Muhammad Arsyad al-Banjari (1712-1810), dalam kitabnya, Tubfat al-Râghibîn fî Bayân Haqîaat al-Mu minîn wa Mâ Yufsidu min Riddat al-Murtaddîn. ${ }^{49}$ Untuk kasus pemberian sesajen, Syekh Arsyad al-Banjari menulis:

Syabdan, bahwa telah terdabulu perkataan babwasanya sanggar dan buang pesilib itu bid'ah haram yang amat keji karena mengandung ia akan beberapa pekerjaan yang ijma' sekalian ulama atas baramnya. Maka barang siapa menghalalkan pekerjaan itu, maka jadilah ia kafir murtad dengan tiada kbilaf sama ada dikerjakan pekerjaan itu atau tiada. Dan barangsiapa mengerjakan dia pekerjaan itu dengan tiada dibalalkan akan dia, tetapi di'itikadkannya bahwa yang disanggar dan yang diberi pesilib itu memberi bekas ia dengan perangainya pada penyakitnya dan mewarasi, dan menolakkan bahaya maka orang itu jadi

${ }^{48}$ Baca dalam Ali Romdhoni (ed.), Nalar Islam Nusantara: Studi Islam ala Mubammadiyah, al-Irsyad, Persis, dan NU (Jakarta: Direktorat Pendidikan Tinggi Islam Depag RI, 2007), 107-112 \& 243-244.

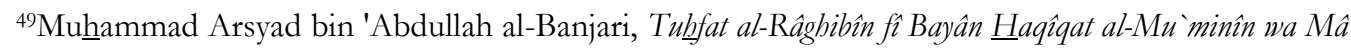
Yufsidu min Riddat al-Murtaddìn (Banjarmasin: Toko Buku Murni, 1983). 
kafir dengan ittifak sekalian ulama. Dan barangsiapa mengi'tikadkan yang demikian itu memberi bekas dengan kuat yang dijadikan Allab Ta'ala dalamnya, maka orang itu jadi kafir, tetapi dengan ikhtilaf mereka itu, dan jadi bid'ah fasik ia dengan tiada khilaf mereka itu. Dan barangsiapa mengerjakan itu dengan tiada dihalalkannya akan dia dan tiada dii'tikadkannya akan dia memberi bekas pada suatu juapun, maka orang itu jadi bid'ah fasik dengan perbuatannya yang demikian itu, maka atas tiap-tiap hal wajiblah orang yang menghalalkan dan mengerjakan pekerjaan itu segera taubat dan minta ampun kepada Allab Ta'ala dengan segala syaratnya dan janganlah ia putus asa daripada rahmat Allah. ${ }^{50}$

Kecaman keras tokoh ulama besar yang sangat disegani di Kalimantan Selatan tersebut tampaknya cukup efektif dan berhasil dalam meluruskan kepercayaan masyarakat muslim Banjar, khususnya ketika mereka menggelar tradisi-tradisi budaya yang di dalamnya melibatkan semacam sesajen-sesajen. Efektivitas dan keberhasilan kritik Syekh Arsyad al-Banjari dalam hal ini terbukti dari tidak adanya lagi ditemukan masyarakat yang mengakui bahwa sesajen yang mereka siapkan dalam upacaya baayun mulud dipersembahkan kepada roh-roh gaib atau makhluk halus yang dapat berpengaruh terhadap kehidupan mereka. Perangkat piduduk (sesajian) yang mereka siapkan, demikian pula beragam aksesoris yang menghiasi ayunan, pada kenyataannya lebih dipandang dari sisi makna simbolik yang terkandung di dalamnya.

\section{Motivasi Sosiologis}

Acara baayun mulud yang digelar secara massal di wilayah Banjarmasin jelas bukanlah sebuah acara sederhana, tetapi sebuah acara yang menuntut kebersamaan dan keterlibatan berbagai pihak dalam masyarakat. Semua pihak yang terlibat dari beragam status dan tingkat stratifikasi sosial yang ada telah berkontribusi positif bagi suksesnya pelaksanaan acara tersebut.

Suasana kebersamaan telah tampak sejak dari persiapan pelaksanaan acara, di mana masyarakat bergotong-royong mempersiapkan segala sesuatunya untuk kelancaran pelaksanaan acara ini. Mereka yang kaya, sebagiannya menjadi donatur, sementara sebagian yang lain menyumbangkan alat-alat untuk dipergunakan dalam acara baayun mulud. Suasana kebersamaan dan kekompakan seperti ini sangatlah langka di tengahtengah perkembangan masyarakat kota yang cenderung mengarah pada pola hidup individualistis.

${ }^{50} \mathrm{Abu}$ Daudi, Transliterasi Kitab Tubfaturraghibin (Martapura: Yapida, 2000), 46. "Sanggar" atau "menyanggar" artinya: memberikan sesajen kepada leluhur. Sedangkan "membuang pesilih" artinya: membuang pakaian yang pernah dipakai dengan tujuan membuang sial. 
Pada saat berlangsungnya acara baayun mulud, suasana kebersamaan, kekeluargaan, dan kemeriahan tampak semakin terasa, khususnya di antara keluarga para peserta. Beragam aksesoris yang menghiasi ayunan, demikian pula sesajen yang dihamparkan di sekitar ayunan, menjadi ajang rebutan di antara pihak keluarga peserta yang dari awal telah berkerumun di sekitar lokasi ayunan.

\section{Motivasi yang Bersifat Politik-Budaya}

Kesan motivasi yang bersifat politi-budaya ini dapat terasa pada pelaksanaan upacara baayun mulud yang diadakan khususnya di depan makam Sultan Suriansyah Kelurahan Kuin Utara Kecamatan Banjarmasin Utara. Panitia penyelenggara acara ini sebagian besarnya adalah pengurus makam yang sekaligus juga merupakan keturunan Sultan Suriansyah. Dukungan dana dan sejumlah peralatan yang digunakan dalam acara baayun mulud pun diberikan oleh mereka yang diketahui publik sebagai keturunan Sultan Suriansyah, dalam hal ini: Raja Muda Banjar, Gt. Khairul Shaleh dan Pimpinan Umum Banjarmasin Post, Gt. Rusdi Effendi.

Sebagaimana diklaim oleh panitia penyelenggara bahwa tradisi baayun mulud ini sebenarnya merupakan tradisi yang sudah lama dikenal oleh orang Banjar. Dahulunya, ia merupakan budaya religius khas masyarakat Banjar yang selalu digelar ketika Kesultanan Banjar masih eksis. Oleh karena itu, dengan tujuan untuk "menimbulakan batang nang tinggalam" (menghidupkan kembali tradisi yang sudah lama terlupakan) tradisi ini kembali digelar. Semangat untuk melakukan Re-eksistensi budaya khas Banjar ini tentunya mengingatkan orang juga akan Kesultanan Banjar yang eksistensinya berusaha ditegaskan kembali oleh sebagian anggota keturunannya. Dalam hal ini, penobatan gelar Raja Muda Banjar, terhadap Bupati Martapura, Gusti Khairul Shaleh beberapa waktu sebelumnya merupakan moment yang sangat terkait dengan usaha ini.

Pihak pemerintah Provinsi Kalimantan Selatan dan juga pemerintah Kota Banjarmasin tentu saja sangat mendukung digelarnya upacara baayun mulud di bulan Rabi'ul Awwal ini, karena merupakan event budaya yang patut dijaga kelestariannya. Selain sebagai cerminan dari tradisi unik khas budaya masyarakat Banjar, penyelenggaraan acara massal ini juga berdampak pada peningkatan pendapat sebagai warga masyarakat, khususnya mereka yang terlibat dalam membuat beragam aksesoris berupa anyam-anyaman dan kue-kue yang disediakan guna melengkapi pelaksanaan acara tradisi baayun mulud.

\section{Penutup}

Sebagian masyarakat Banjar dalam melaksanakan perayaan atau peringatan hari kelahiran Nabi Muhammad Saw., diisi dengan acara mengayun anak atau orang dewasa, yang lazim disebut dengan istilah baayun mulud. Adapun tujuan dilaksanakan dan kepercayaan 
yang mendasari pelaksanaan acara baayun mulud ini adalah ada yang bersifat religius, ada yang bersifat sosiologis, dan ada pula yang bersifat politik-budaya. Motivasi religius dari penyelenggaraan acara baayun mulud ini di antaranya adalah adanya kepercayaan akan terkabul segala hajat; mendapat berkah, kesehatan, keselamatan, sembuh dari sakit, anak tidak nakal/rewel dan karena nadzar yang dikabulkan Allah swt. Adapun motivasi yang bersifat sosiologis dari acara ini, di antaranya adalah bahwa pelaksanaan acara baayun mulud ini dinilai sangat berguna dalam menumbuhkan semangat kebersamaan, gotong-royong dan persatuan di tengah masyarakat kota yang cenderung individualistis dewasa ini. Sedangkan motivasi yang bersifat politik-budaya, di antaranya dapat dirasakan dari pernyataan pihak panitia penyelenggara yang dengan tegas menyatakan bahwa acara ini digelar dalam rangka menghidupkan kembali tradisi yang sudah terlupakan, padahal ia pernah eksis di masa Kesultanan Banjar. Seiring dengan penegasan kembali eksistensi Kesultanan Banjar, maka eksistensi budaya yang pernah ada di masa kejayaan Kesultanan ini pun berusaha dibangkitkan kembali. 


\section{DAFTAR PUSTAKA}

Abdullah, M. Amin. Studi Agama: Normativitas atan Historisitas?. Yogyakarta: Pustaka Pelajar, 1996.

al-'Amanily, Ja'far Murtadha. Perayaan Maulid, Khaul dan Hari-hari Besar Islam Bukan Sesuatu yang Haram, terj. Masykur Ab. Bandung: Pustaka Hidayah, 1996.

Badan Pusat Statistik Kota Banjarmasin. Kecamatan Banjarmasin Tengah dalam Angka: Banjarmasin Tengab In Figures 2010.

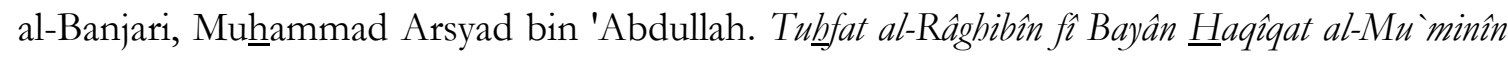
wa Mâ Yufsidu min Riddat al-Murtaddìn. Banjarmasin: Toko Buku Murni, 1983.

Basuni, Ahmad. Nur Islam di Kalimantan Selatan, (Sejarah Masuknya Islam di Kalimantan. Surabaya: PT. Bina Ilmu,1986.

bin Bâz, 'Abd al-'Azîz bin 'Abdullah. Fatâwâ al-Mar'ah al-Muslimah. Kairo: Dâr Ibn al-Jauzî, 2005.

bin Fauzân, Shâliḥ, bin 'Abdillah al-Fauzân, Kitâb al-Taubîd. al-Mamlakah al-'Arabiyyah alSa'udiyyah: Wizârah al-Syu'ûn al-Islâmiyyah wa al-Awqâf wa al-Da'wah wa alIrsyâd, $1423 \mathrm{H}$, juz I.

Bustanuddin, Agus. Agama dalam Kehidupan Manusia. Jakarta: PT.RajaGrafindo Persada, 2006.

Daud, Alfani. Islam dan Budaya Banjar. Jakarta PT RajaGrafindo Persada, 1997.

Daudi, Abu. Transliterasi Kitab Tubfaturraghibin. Martapura: Yapida, 2000.

Khadziq. Islam dan Budaya Lokal. Yogyakarta: Teras, 2009.

Hasyim, Umar. Syetan Sebagai Tertuduh dalam Masalah Sibir Tahayul Pedukunan dan Azimat. Surabaya: PT. Bina Ilmu, 1989.

Ibn Qayyim al-Jauziy, Imam Syamsuddin Abi Abdillah. Masalah Ruh, terj. Jamaluddin Kafie. Surabaya: PT. Bina Ilmu, 1979. 
Ideham, M. Suriansyah. et.al. Urang Banjar dan Kebudayaannya. Banjarmasin: Badan Penelitian dan Pengembangan Daerah Provinsi Kalimantan Selatan, 2005.

Mujiburrahman. Mengindonesiakan Islam: Representasi dan Ideologi. Yogyakarta: Pustaka Pelajar, 2008.

Mochrani. Agama dan Kemasyarakatan. Banjarmasin: PPPTAI/IAIN, 1982.

Nordiansyah. Sinkretisme. Banjarmasin: Fakultas Ushuluddin IAIN Antasari, 1982.

Romdhoni, Ali (ed.). Nalar Islam Nusantara: Studi Islam ala Muhammadiyah, al-Irsyad, Persis, dan NU. Jakarta: Direktorat Pendidikan Tinggi Islam Depag RI, 2007.

Sani, Mukhyar. Dakwah Islam dan Perkembangannya di Kalimantan Selatan. Banjarmasin, AlHadharah, 2003.

Shihab, Alwi. Antara Tasawnf Sunni dan Tasawnf Falsafi: Akar Tasawuf di Indonesia. Jakarta: Pustaka Iiman, 2009.

Siagian, Seno Harbangan. Agama-Agama di Indonesia. Semarang: Setia Wacana, 1987.

Sjarifuddin. et.al. Sejarah Banjar. Banjarmasin: Badan Penelitian dan Pengembangan Daerah Provinsi Kalimantan Selatan, 2004.

Subagya, Rachmat. Kepercayaan Kebatinan, Kerohanian, dan Agama, Jakarta: Yayasan Kanisius. 1970.

Tambusai, Musdar Bustaman. Buku Pintar Jin, Sibir dan Ruqyah Syar'iyyah. Jakarta Timur: Pustaka al-Kautsar, 2010.

Zamani, Ahd.. et al. Pemahaman Hadis-hadis Nur Mubammad Menurut Ulama Kota Banjarmasin. Banjarmasin: Antasari Press, 2008.

Wajidi. Akulturasi Budaya Banjar di Banua Halat. Yogyakarta: Pustaka Book Publisher, 2011. 